\title{
Spatial Variability of Organic Matter and Phosphorus Cycling in Rhône River Prodelta Sediments (NW Mediterranean Sea, France): a Model-Data Approach
}

\author{
Ait Ballagh Fatima Ezzahra 1,2, Rabouille Christophe ${ }^{1, ~}{ }^{*}$, Andrieux-Loyer Francoise ${ }^{3}$, \\ Soetaert Karline 4, Lansard Bruno ${ }^{1}$, Bombled Bruno ${ }^{1}$, Monvoisin Gael 5, Elkalay Khalid ${ }^{2}$, \\ Khalil Karima ${ }^{2}$
}

1 ViolaineLaboratoire des Sciences du Climat et de l'Environnement, Laboratoire Mixte CEA-CNRSUVSQ, IPSL et Université Paris-Saclay, CEA-Orme des Merisiers, 91191, Gif sur Yvette, France

2 Laboratory of Applied Sciences for the Environment and Sustainable Development, Essaouira School of Technology, Cadi Ayyad University, Km 9, Route d'Agadir, BP. 383, Essaouira Aljadida, Morocco 3 Ifremer ,DYNECO PELAGOS, ZI Pointe du Diable, 29280, Plouzané, France

${ }^{4}$ Department of Estuarine and Delta Systems, Royal Netherlands Institute for Sea Research (NIOZ) and Utrecht University, P.O. Box 140, 4400 AC, Yerseke, The Netherlands

${ }^{5}$ GEOPS, Université Paris-Saclay et CNRS, Campus d'Orsay, Orsay, France

* Corresponding author : Christophe Rabouille, email address : rabouille@Isce.ipsl.fr

\begin{abstract}
:
The Mediterranean Sea (MS) is a large oligotrophic sea whose productivity is sensitive to riverine nutrient inputs. More specifically, phosphorus $(P)$ river supply is crucial for the MS, with an important role of the estuarine/deltaic filter especially for the storage and recycling in sediments. A benthic dataset from the Rhône River prodelta was used to derive $P$ budgets, by means of an early diagenetic model including the benthic $\mathrm{P}$ cycle. The model was fitted to pore water profiles of oxygen, nitrate, sulfate, dissolved inorganic carbon, ammonium, oxygen demand units, dissolved inorganic phosphorus (DIP) and solid data (organic carbon (OC), Fe-bound $\mathrm{P}$, Ca-bound $\mathrm{P}$ and organic $\mathrm{P}$ ). Results indicated that the intensity of biogeochemical processes occurring below the sediment-water interface decreased from the river mouth to the adjacent continental shelf with decreasing integrated rates of OC mineralization (160$10 \mathrm{mmol} \mathrm{m}-2$ day-1). The organic $P$ mineralization was intense near the river mouth and decreased offshore (1196-80 $\mu \mathrm{mol} \mathrm{m-2}$ day-1). Its contribution to DIP release was large (>90\%). Fe-bound $\mathrm{P}$ had a key role in transferring $P$ to deeper layers. These deltaic sediments played an important role as a source of regenerated DIP. A significant part of DIP was recycled to the overlying waters (72-94\%), representing $25 \%$ of the riverine DIP discharge. Simultaneously, $6-28 \%$ of DIP produced in sediments was buried as Ca-bound P. Overall, this study highlighted the importance of deltaic sediments as an additional source of DIP to the coastal sea, and a minor but permanent sink of phosphorus as solid P burial.
\end{abstract}

Keywords: Organic matter, Phosphorus, Mediterranean Sea, Rhône River prodelta, Sediment, Modelling 


\section{Acknowledgements}

20 We would like to thank the captain and the crew members of N.O. Tethys II (INSU/CNRS) for

21 their assistance during sampling at sea. We are grateful to Laurie Brethous, and Anouk

22 Villedieu who provided help at sea during sampling and in the laboratory for measurements. 
23 Florian Caradec and Emilie Rabiller are acknowledged for their help during P-speciation

24 measurements at IFREMER's laboratory. We thank the two anonymous reviewers whose 25 comments greatly improved the quality of this manuscript. This work was supported by the 26 INSU/EC2CO-MissRhoDia project, the French State program "Investissement d'avenir" run by

27 the National Research Agency (AMORAD project ANR-11-RSNR-0002) and the CEDoc 28 cooperation research project between Morocco and France. This is LSCE publication number 29 XXXX. 
Phosphorus is a key macronutrient for all life forms (Ruttenberg 1992; Tyrrell 1999). It

53 is a typical limiting element of primary production in marine areas (Benitez-Nelson 2000), such

54 as the Mediterranean Sea, with a prominent role in the Eastern part (Krom et al. 1991). Overall,

55 particulate $\mathrm{P}$ is partitioned as $\mathrm{P}$ associated to organic matter, Fe-oxyhydroxides (henceforth

56 called Fe-oxides), aluminum oxides, vivianite and apatite (Lebo 1991). Meybeck (1982)

57 showed on a global scale that rivers deliver globally $21 \times 10^{12} \mathrm{~g} \mathrm{P} \mathrm{yr}^{-1}$ to the sea. However, only

$58 \quad 10 \%$ of this flux is available to the marine biota, because more than $90 \%$ of the P load is bound

59 to particles and, therefore, settle rapidly to the seafloor in the coastal zones.

Although eutrophication has existed throughout the geological times (Nixon 1995;

61 Cloern 2001), the second half of the $20^{\text {th }}$ century has witnessed the dramatic increase of

62 anthropogenic activities (i.e. agricultural practice, industrial and urban waste, dam building and

63 perturbation of hydrological cycles and sediment loads) which degraded deltaic and coastal

64 ecosystems and altered biogeochemical cycles of carbon $(\mathrm{C})$, nitrogen $(\mathrm{N})$ and phosphorus $(\mathrm{P})$

65 in these vulnerable areas (Howarth et al. 1996; Vitousek et al. 1997; Jackson et al. 2001; Diaz

66 and Rosenberg 2008; Wilkinson 2017). These anthropogenic changes led also to large organic

67 matter inputs (McKee et al. 2004; Canfield et al. 2005; Bianchi and Allison 2009; Syvitski et

68 al. 2009) and intense nutrient ( $\mathrm{N}$ and $\mathrm{P}$ ) loads to coastal margins compared to the middle of the

$6920^{\text {th }}$ century (Downing et al. 1999; Cloern 2001; Ludwig et al. 2009). The nutrient enrichment 
stimulates primary production and phytoplankton growth in adjacent coastal waters (Milliman and Meade 1983; Cloern 2001), which leads to phytoplankton proliferation, alteration in species compositions, hypoxia and deterioration of water quality (Smith et al. 1999).

River-dominated Ocean Margins (RiOMar) are important interfaces, connecting approximatively $87 \%$ of land surfaces to the oceans (Ludwig and Probst 1998; McKee et al. 2004). They support a large human population and provide ecological, economical and societal development due to their richness (Batker et al. 2014). They are important burial sites and preserve more than $40 \%$ of organic matter in the world ocean (Muller-Karger et al. 2005; Burdige 2007). Their sediments are characterized by high spatio-temporal variability of riverine discharge to the seafloor and strong biogeochemical gradients offshore (McKee et al. 2004; Lansard et al. 2009; Rassmann et al. 2016).

The Mediterranean Sea is a quasi-enclosed marginal sea $(0.8 \%$ of the world ocean surface; Powley et al. 2017), often characterized as a replicate of an open ocean (Antoine and Morel 1995). This regional sea is oligotrophic, with lower nutrient concentrations ( $\mathrm{N}$ and $\mathrm{P}$ ) compared to oceanic areas (Dugdale and Wilkerson 1988), especially for dissolved inorganic phosphorus. A west-east gradient of decreasing P concentrations (Moutin et al. 2012) leads to higher primary production in the western Mediterranean Basin (Van Den Broeck and Moutin 2002; Moutin and Raimbault 2002). Overall, it has been shown that the P availability plays a key role as a limiting nutrient in the entire Mediterranean Sea (Krom et al. 1991; Diaz et al. 2001).

Rivers discharge large amounts of sediment and freshwater in the Mediterranean Sea (Ludwig et al. 2009). After the Nile damming, the Rhône River became the most important source of terrestrial organic matter, nutrients and freshwater to the Mediterranean Sea (Antonelli et al. 2008; Ludwig et al. 2009). The average particulate discharge from the Rhône River to the Mediterranean was estimated to $7.4 \mathrm{Mt} \mathrm{y}^{-1}$ (Pont et al. 2002), with large seasonal 
and interannual variability. Overall, riverine fluxes at the Mediterranean Sea's boundaries and the controlling processes at the river-sea connection are key for understanding P cycling and its control in this oligotrophic sea, especially sediments where particulates from the river rapidly settle and are biogeochemically transformed.

Reactive $\mathrm{P}$ reaching the sediment-water interface is mainly associated to organic matter with a molar $\mathrm{C} / \mathrm{P}$ ratio that is determined by its origin. Additional inputs of $\mathrm{P}$ are bound to $\mathrm{Fe}-$ oxides and as carbonate fluorapatite (CFA; Emsley 1980; Sundby et al. 1992; Ruttenberg and Berner 1993; Slomp et al. 1996; Delaney 1998; Andrieux-Loyer and Aminot 2001; Slomp et al. 2004; Ruttenberg 2014). As organic matter is progressively buried below the sediment-water interface, the non-refractory fraction is degraded via a sequence of biogeochemical processes, releasing DIP to the pore waters (Krom and Berner 1981; Sundby et al. 1992; Joshi et al. 2015). In the oxic zone of sediments, this dissolved phase may diffuse to the overlying waters or be adsorbed onto sediment Fe-oxide surfaces reversibly and irreversibly (Fe-bound P; Syers et al. 1973; Froelich 1988; Fox 1990; Balls 1994; Filippelli and Delaney 1996; Anschutz et al. 1998; Slomp et al. 1998; Cade-Menun et al. 2019). In the anoxic layers, DIP concentrations generally show a large increase due to organic $\mathrm{P}$ mineralization and $\mathrm{P}$ release from Fe-oxides dissolution, as the latter are used as a terminal electron acceptor in the mineralization process (Krom and Berner 1981). Therefore, iron reduction can have a significant role in phosphorus cycle as it has been shown for sulfur cycle (Thamdrup et al., 1994). DIP can ultimately be taken up by an authigenic mineral such as carbonate fluorapatite (CFA) through precipitation with $\mathrm{Ca}^{2+}$ (Ruttenberg and Berner 1993) or by vivianite (Emerson and Widmer 1978; Egger et al. 2015; Dijkstra et al. 2016; Lenstra et al. 2018). This "sink-switching" represents the main long-term sink of reactive $\mathrm{P}$, as long as the authigenic mineral acts as an insoluble phase in deep sediments without being reprocessed during the diagenetic processes (Ruttenberg and Berner 1993; Slomp et al. 1998; Kraal et al. 2015). The P regeneration and sink-switching needs to be better studied 
in subaqueous deltaic sediments subjected to high nutrient loads. Considering the large P inputs

121 from the Rhône River, it is necessary to determine the biogeochemical P dynamics and the fate of $\mathrm{P}$ input to the deltaic sediments: release vs burial with authigenic minerals.

Biogeochemical modelling by reactive-transport models has been largely used to the

124 early diagenesis studies in the aquatic sediments (Berner 1980; Rabouille and Gaillard 1991;

125 Tromp et al. 1995; Boudreau 1996; Soetaert et al. 1996; Wang and Van Cappellen 1996;

126 Boudreau 1997; Wijsman et al. 2002; Berg et al. 2003; Canavan et al. 2006), but the benthic P

127 cycle is rarely incorporated as a function of organic matter mineralization (Canavan and Slomp

128 2006; Gypens et al. 2008; Lenstra et al. 2018) especially in a highly dynamic system. Here, we

129 analyzed spatial variability in the sediment composition, the organic matter transformation and

130 nutrient retention in the Rhône prodelta sediments, in order to quantify the intensity of

131 biogeochemical processes and its effect on the benthic $\mathrm{P}$ cycle.

The present paper aims at quantifying the biogeochemical processes that control

133 phosphorus recycling and trapping in these sediments and at determining the spatial impact of

134 riverine organic matter from the river mouth to the adjacent continental shelf. To this end, we

135 used an early diagenetic model (OMEXDIA, Soetaert et al. 1996), with P diagenesis (Ait

136 Ballagh et al. 2020), and applied it to a dataset of sediment and porewater composition in the

137 biogeochemical gradient of the Rhône River prodelta and shelf sediments, including particulate

138 P speciation.

\section{3. Materials and methods}

\section{$140 \quad$ 3.1.Study site}

The Rhône River (RR; Fig. 1) is the largest river in the Mediterranean Sea in terms of

142 sediment loads, nutrient and freshwater fluxes (Antonelli et al. 2008; Ludwig et al. 2009). The 
$143 \mathrm{RR}$ is $812 \mathrm{~km}$ long, characterized by a catchment area of $97800 \mathrm{~km}^{2}$ originating in the Alps and 144 ending in a delta of $1455 \mathrm{~km}^{2}$ (Pont et al. 2002; Antonelli et al. 2004). Fifty kilometers upstream 145 from the river mouth, the Rhône River splits into two unequal branches : the eastern channel 146 (Grand Rhône, $50 \mathrm{~km}$ long, also called Rhône), which discharges 80-90\% of the freshwater in 147 the Gulf of Lions, and the western channel (Petit Rhône, $70 \mathrm{~km}$ long) that carries 10-20\% of 148 total discharge (Ibañez et al. 1997; Sabatier et al. 2006; Provansal et al. 2012). During flood 149 events, $80 \%$ to $90 \%$ of annual particulate loads are discharged into the Rhône River delta, from 150 the catchment area (Arnau et al. 2004; Ollivier et al. 2010; Eyrolle et al. 2012). The remaining 151 loads originate from the soil erosion in the catchment area, in stream production or resuspension 152 of river sediments from the upstream during lower freshwater discharges (Eyrolle et al. 2012). 153 Overall, the mean water discharge at the Rhône River mouth is $1700 \mathrm{~m}^{3} \mathrm{~s}^{-1}$, with a peak 154 discharge of $13000 \mathrm{~m}^{3} \mathrm{~s}^{-1}$ in December 2003 (Lochet and Leveau 1990; Ibañez et al. 1997; Pont 155 et al. 2002; Arnau et al. 2004). oriented by wind regimes close to the Rhône River mouth and by the River flow (Estournel et al. 1997; Naudin et al. 1997; Gatti et al. 2006). Consequently, the delivered loads of particulate material to the delta are mostly transported in the SW direction and some are ultimately driven to the adjacent continental shelf. The largest share of the riverine inputs is deposited at the seafloor near the river mouth, leading to the formation of a deposition fan called prodelta (Got and Aloisi 1990; Lansard et al. 2007). Consequently, the water depth increases from $10 \mathrm{~m}$ at

163 the river mouth to $75-90 \mathrm{~m}$ on the adjacent continental shelf.

The decrease of sediment loads with distance from the Rhône River mouth is accompanied by a progressive aging of organic particles (Cathalot et al. 2013). The decreasing

166 sediment deposition offshore gives rise to a large biogeochemical gradient from the Rhône 167 River mouth to the continental shelf (Cathalot et al. 2010; Pastor et al. 2011; Rassmann et al. 
2016). Concerning the DIP inputs from the Rhône River, Ludwig et al. (2009) showed an

169 increase of DIP loads from 1970 to around 1985, followed by a decrease that may be related to

170 the mitigation of pollution (i.e., the ban of $\mathrm{P}$ detergents and/or the upgrading of the waste water

171 treatment plants).

The Rhône prodelta (named because of its prograding properties) is characterized by

173 two regions: the proximal zone located near the river mouth at a water depth of around 20 meters and a sedimentation rate of $20-35 \mathrm{~cm} \mathrm{yr}^{-1}$ depending on the period investigated and the tracer used (Charmasson et al. 1998; Radakovitch et al. 1999; Miralles et al. 2005; Lansard et al. 2007) whereas the prodelta zone is located further at 30-65 meters depth and displays

177 sedimentation rates of 1-2 $\mathrm{cm} \mathrm{yr}^{-1}$. The adjacent continental shelf extends further away from 178 the prodelta and has sedimentation rates of less than $0.1 \mathrm{~cm} \mathrm{yr}^{-1}$.

\subsection{Measurements}

\subsubsection{Sampling stations}

The sampling cruise MissRhoDia was carried out aboard the RV Tethys II in May 2018.

Nine stations were sampled between 2 and $18 \mathrm{~km}$ from the Rhône River mouth, in the proximal

183 (stations A, Z and AZ), prodelta (stations AK, K, B and L) and distal (stations $\mathrm{C}$ and $\mathrm{E}$ ) domains

184 over a southwest transect, corresponding to the main direction of the river plume. The locations

185 of sampling stations are shown in Figure 1 and the main characteristics are in Table 1. Sediment 186 cores were collected using an UWITEC $^{\circledR}$ single corer $(9.5 \mathrm{~cm}$ of inner diameter, $60 \mathrm{~cm}$ of 187 length) for porewater and solid phases analysis. Bottom water samples were taken with a 12-L 188 Niskin $^{\circledR}$ bottle as close as possible to the seafloor (approximately $1 \mathrm{~m}$ ). Salinity and temperature

$189\left({ }^{\circ} \mathrm{C}\right)$ were measured using a salinometer with a precision of \pm 0.1 and a thermometer with a 190 precision of $\pm 0.1^{\circ} \mathrm{C}$, respectively (Table 1 ). 
The distribution of $\mathrm{O}_{2}$ and $\mathrm{pH}$ at the sediment-water interface were measured using in

193 situ microelectrode with a benthic microprofiler (Unisense ${ }^{\circledR}$ ) (Rabouille et al. 2003; Lansard

194 et al. 2008; Cathalot et al. 2010; Rassmann et al. 2016; 2020). The measurements of 4-5 vertical

195 depth $\mathrm{O}_{2}$ profiles per station and $2 \mathrm{pH}$ profiles were achieved with a vertical resolution of 200

$196 \mu \mathrm{m}$ near the sediment-water interface. The dissolved $\mathrm{O}_{2}$ concentrations were measured by

197 polarographic oxygen microelectrodes that were provided with a built-in reference and internal

198 guard cathode (Revsbech 1989). The microelectrodes were calibrated with a two-point

199 calibration technique using the bottom water oxygen concentration determined by Winkler

200 titration (Grasshof et al. 1983) and the anoxic pore waters of the sediment (Cai and Sayles

201 1996). The $\mathrm{pH}$ microelectrodes were calibrated by NBS $\mathrm{pH}$ buffers ( $\mathrm{pH} 4.01,7.00$ and 9.00)

202 which provided the slope of the sensor response to $\mathrm{pH}$ and which estimated the $\mathrm{pH}$ variation.

203 The measurement of seawater $\mathrm{pH}$ in bottom waters was carried out by spectrophotometry with 204 unpurified m-cresol purple (Clayton and Byrne 1993; Dickson et al. 2007) and is reported on 205 the total proton scale $\left(\mathrm{pH}_{\mathrm{T}}\right)$. The precision of the dissolved $\mathrm{O}_{2}$ measurement was of $\pm 0.5 \mu \mathrm{M}$, 206 whereas the uncertainty of measured $\mathrm{pH}$ was $\pm 0.01 \mathrm{pH}$ units.

\subsubsection{Ex situ measurements of solid and pore water profiles}

In order to determine the sediment porosity, a core was sliced with a resolution of $2 \mathrm{~mm}$

209 for $0-10 \mathrm{~mm}$ depth, $5 \mathrm{~mm}$ for $10-60 \mathrm{~mm}$, and $10 \mathrm{~mm}$ until the bottom of the core. The sediment

210 porosity was calculated using water contents (the difference between the wet and dried weight

211 after one week at $60^{\circ} \mathrm{C}$ ) and an averaged sediment density of $2.65 \mathrm{~g} \mathrm{~cm}^{-3}$. The sediment porosity

212 was then corrected by the bottom water salinity.

A second sediment core was processed within 1-2 hours after sampling for the extraction

214 of pore waters by its introduction in a glove bag flushed with $\mathrm{N}_{2}$ atmosphere in order to avoid 
216 a mean pore size of $0.1 \mu \mathrm{m}$ (Seeberg-Elverfeldt et al. 2005). After collection, the pore water

$217 \mathrm{Fe}^{2+}$ and the total dissolved Fe were measured using the ferrozine method (Stookey 1970). Pore 218 waters were poisoned using $\mathrm{HgCl}_{2}$ for total alkalinity (TA) and dissolved inorganic carbon

219 (DIC), acidified with $\mathrm{HCl}$ for $\mathrm{SO}_{4}{ }^{2-}$ measurements, and stored at $4{ }^{\circ} \mathrm{C}$ until laboratory analysis.

220 Subsamples for $\mathrm{NH}_{4}{ }^{+}, \mathrm{NO}_{3}{ }^{-}$and DIP measurements were frozen on board. The pore water $\mathrm{NH}_{4}{ }^{+}$ 221 concentration was diluted and quantified by the indophenol blue method (Grasshof et al. 1983), 222 while the pore water $\mathrm{NO}_{3}{ }^{-}$concentration was measured using the Vanadium chloride reductant 223 after dilution, followed by the addition of NEDD/sulphanilamide and the colorimetric method 224 (Hansen and Koroleff 1999; Schnetger and Lehners 2014). The uncertainties of the methods for $225 \mathrm{NH}_{4}{ }^{+}$and $\mathrm{NO}_{3}{ }^{-}$were $5 \%$ and $2 \%$, respectively.

The pore water DIC concentrations were quantified with a DIC analyzer (Apollo 227 SciTech $^{\circledR}$ ), by the use of $1 \mathrm{ml}$ of the sample volume with 4-7 replicates as described previously 228 by Rassmann et al. (2016). The DIC method was calibrated using certified reference materials 229 (oceanic $\mathrm{CO}_{2}$ measurements, Scripps Institution of Oceanography-batch $\mathrm{n}^{\circ} 136$ ) which provided 230 an uncertainty of $0.3 \%$. The pore water $\mathrm{SO}_{4}{ }^{2-}$ concentrations were diluted by a factor of 100 and 231 measured using ion chromatography on an ICS 1000 chromatograph with an AS14 column and 232 an AG14 guard column, both in 4mm diameter (Dionex) (Rassmann et al. 2020). The 233 uncertainty of this method was of $\pm 1.6 \%$.

234 For the pore water DIP, the measurements were performed spectrophotometrically 235 (Murphy and Riley 1962) at $880 \mathrm{~nm}$ on $3 \mathrm{ml}$ of each sample, using a mixed reagent prepared 236 daily from sulfuric acid $\left(\mathrm{H}_{2} \mathrm{SO}_{4}\right)$, potassium antimony (III) oxytartrate hemihydrate $237\left(\mathrm{~K}(\mathrm{SbO}) \mathrm{C}_{4} \mathrm{H}_{4} \mathrm{O}_{6} .1 / 2 \mathrm{H}_{2} \mathrm{O}\right)$, ammonium molybdate $\left(\left(\mathrm{NH}_{4}\right)_{6} \mathrm{Mo}_{7} \mathrm{O}_{24}, 4 \mathrm{H}_{2} \mathrm{O}\right)$ and ascorbic acid $238\left(\mathrm{C}_{6} \mathrm{H}_{8} \mathrm{O}_{6}\right)$. The precision of the method was $1 \%$. 
Another sediment core was sampled and freeze-dried for 48 hours, and ground for 241 further analysis of the $\mathrm{P}$ solid forms. The sedimentary $\mathrm{P}$ pools were separated using the sequential extraction method as detailed in Andrieux-Loyer et al. (2008) and adapted from widespread extraction methods (Psenner et al. 1988; Ruttenberg 1992).

Fe-bound $\mathrm{P}$ (including the Fe-oxides bound $\mathrm{P}$ and the vivianite) was extracted by 0.1 mol $\mathrm{l}^{-1}$ of Dithionite-Bicarbonate $\left(8 \mathrm{~h}, 20^{\circ} \mathrm{C}\right)$. In a second step, authigenic Ca-bound $\mathrm{P}$ (including 246 carbonate fluorapatite $\mathrm{Ca}_{5}\left(\mathrm{PO}_{4}, \mathrm{CO}_{3}\right)_{3} \mathrm{~F}$, biogenic hydroxyapatite $\mathrm{Ca}_{10}\left(\mathrm{PO}_{4}\right)_{6}(\mathrm{OH})_{2}$ and $\mathrm{CaCO}_{3}$ 247 bound $\mathrm{P}$ ) was quantified on the remaining fraction by $1 \mathrm{~mol} \mathrm{l}^{-1}$ of $\mathrm{Na}$-acetate buffer $(\mathrm{pH}=4$, 248 $\left.6 \mathrm{~h}, 20^{\circ} \mathrm{C}\right)$ then washed by $1 \mathrm{~mol} \mathrm{l}^{-1}$ of $\mathrm{MgCl}_{2}\left(\mathrm{pH}=8,0.5 \mathrm{~h}, 20^{\circ} \mathrm{C}\right)$. Then, the detrital $\mathrm{P}$ was extracted using $1 \mathrm{~mol} \mathrm{l}^{-1}$ of $\mathrm{HCl}$ (overnight). Total $\mathrm{P}$ was determined non-sequentially by $1 \mathrm{~mol}$ $1^{-1} \mathrm{HCl}$ treatment overnight after sediment ignition at $550^{\circ} \mathrm{C}(4 \mathrm{~h})$, while the inorganic $\mathrm{P}$ referring to the sum of $\mathrm{P}$-forms (Fe-bound $\mathrm{P}, \mathrm{Ca}-$ bound $\mathrm{P}$ and detrital $\mathrm{P}$ ), was extracted with $1 \mathrm{~mol} \mathrm{l}^{-1}$ $252 \mathrm{HCl}$ before sediment ignition, in order to ensure the measurements efficiency. Organic $\mathrm{P}$ was 253 then quantified by the difference between total P and inorganic P (Andrieux-Loyer et al. 2008).

\subsection{Model description}

The modelling was performed by a steady-state version of the diagenetic model OMEXDIA (Soetaert et al. 1996; Khalil et al. 2018), implemented in the R software, using the 257 R-package ReacTran (Soetaert and Meysman 2012) and extended to include the benthic P cycle 258 (Slomp et al. 1996; Ait Ballagh et al. 2020). The steady-state model assumption in our study 259 allowed to understand the relative contribution of biogeochemical processes involved in the 260 benthic $\mathrm{P}$ cycle in dynamic system outside floods events. This assumption is based on a 261 stationary state observed over several years (2007-2015) during the spring-summer season, 262 which allows typical diagenetic situation to be investigated using a steady-state model 263 (Rassmann et al. 2020). This condition was achieved by setting the rates of changes to 0 (i.e. 
$264 \partial \mathrm{Ci} / \partial \mathrm{t}=0$ ). The model outputs were fitted to the measurements of organic carbon, terminal 265 electron acceptors $\left(\mathrm{O}_{2}, \mathrm{NO}_{3}{ }^{-}, \mathrm{SO}_{4}{ }^{2-}\right)$, products of mineralization $\left(\mathrm{NH}_{4}{ }^{+}, \mathrm{DIP}, \mathrm{DIC}\right.$ and oxygen 266 demand units (ODU; reduced substances during anoxic mineralization)), and solid $\mathrm{P}$ fractions 267 (organic $\mathrm{P}, \mathrm{Fe}-$ bound $\mathrm{P}$ and $\mathrm{Ca}$-bound $\mathrm{P}$ ). The model solves a set of general diagenetic equations 268 (Berner 1980; Boudreau 1997) for dissolved $C_{d}$ and solid $C_{s}$ concentrations (Eqs. 1 and 2), as 269 described below:

$-\frac{\partial}{\partial \mathrm{x}}\left[-\varnothing \mathrm{D}_{\mathrm{s}} \frac{\partial \mathrm{Cd}}{\partial \mathrm{x}}+\omega \emptyset \mathrm{C}_{\mathrm{d}}\right]+\varnothing \sum \mathrm{R}_{\mathrm{d}}+\alpha\left(\mathrm{C}_{\mathrm{d}_{0}}-\mathrm{C}_{\mathrm{d}}\right)=0$

$271-\frac{\partial}{\partial \mathrm{x}}\left[-\mathrm{D}_{\mathrm{B}} \frac{\partial(1-\varnothing) \mathrm{C}_{\mathrm{s}}}{\partial \mathrm{x}}+\omega(1-\emptyset) \mathrm{C}_{\mathrm{s}}\right]+(1-\emptyset) \sum \mathrm{R}_{\mathrm{s}}=0$

Where $C_{d}$ and $C_{s}$ denotes the concentrations of the dissolved and solid species, respectively (in mol per volume of porewater or dry sediment ${ }^{-1}$ ). $\emptyset$ is the sediment porosity $\left(\mathrm{cm}^{3} \mathrm{~cm}^{-3}\right), \mathrm{x}$ is the sediment depth $(\mathrm{cm}), \mathrm{D}_{\mathrm{s}}$ is the diffusion coefficient $\left(\mathrm{cm}^{2} \mathrm{~d}^{-1}\right), \mathrm{D}_{\mathrm{B}}$ is the bioturbation coefficient $\left(\mathrm{cm}^{2} \mathrm{~d}^{-1}\right), \omega$ represents the sedimentation rate $\left(\mathrm{cm} \mathrm{d}^{-1}\right), \sum \mathrm{R}_{\mathrm{d}}$ and $\sum \mathrm{R}_{\mathrm{s}}$ denote the sum of the biogeochemical reactions occurring to dissolved and solid species, respectively. $\alpha$ is the depth-profile bioirrigation rate, while $C_{d_{0}}$ is the bottom water concentration of dissolved phases $\left(\mu \mathrm{mol} 1^{-1}\right)$.

The dissolved species are transported by molecular diffusion and bioirrigation, whereas 280 bioturbation is the main transport process for solid phases. In addition, advection is a common process for all species (Berner 1980; Boudreau 1997; Rabouille \& Gaillard 1991). The sediment compaction is represented in the model by the exponential decrease of porosity (Berner 1980; Rabouille and Gaillard 1991). Below the sediment-water interface, all the mineralization 284 pathways produce $\mathrm{NH}_{4}{ }^{+}$and DIP (Table 2). The labile (FDet) and semi-labile (SDet) fractions 285 of organic carbon are mineralized in the oxic zone by oxygen (OxicMin; Table2, R1). Once the oxygen is totally consumed, the denitrification takes place in suboxic zone and is limited by 
nitrate concentration (Denitrif ; Table 2, R2; Emerson et al. 2004). In the anoxic zone, metal oxides and sulfate are used as next terminal electron acceptors in the mineralization (AnoxicMin; Table 2, R3-4). The ammonium and the other reduced compounds expressed as oxygen demand units (ODU; Berner 1989; Soetaert et al. 1996) are reoxidized by oxygen in the oxic zone (Nitrif and ODUoxid, respectively; Table 2, R5-6). The stoichiometry of organic matter is represented by coefficients $\mathrm{x}$ and $\mathrm{y}$ denoting molar $\mathrm{C} / \mathrm{P}$ and $\mathrm{N} / \mathrm{P}$ ratios, respectively.

for the compounds; the labile and semi-labile fractions of organic carbon (Eq. 3 and Eq. 4), oxygen (Eq. 5), nitrate (Eq. 6), sulfate (Eq. 7), ammonium (Eq. 8), the dissolved inorganic carbon (Eq. 9) and the ODU that are produced by anoxic mineralization and may be lost from the system to form solid substances as a pyrite (Eq. 10; Berner 1970; Soetaert et al. 1996; Rassmann et al. 2020). These equations are depending on the conversion between solid and liquid units $(\vartheta)$.

$$
\vartheta=\rho_{s} \frac{(1-\emptyset)}{\emptyset}
$$

Where $\rho_{S}$ denotes the average density of the sediment particles $\left(\mathrm{g} \mathrm{cm}^{-3}\right)$.

\subsubsection{Benthic phosphorus cycle}

The benthic $\mathrm{P}$ cycle is included in the model to obtain more insight into the $\mathrm{P}$ transformation in the Rhône prodelta sediments. The present model describes the concentration change with depth of pore water DIP $\left(\mu \mathrm{mol} \mathrm{l}^{-1}\right)$ and three forms of particulate $\mathrm{P}$ (organic $\mathrm{P}, \mathrm{Fe}-$ bound $\mathrm{P}$ and $\mathrm{Ca}$-bound $\mathrm{P}\left(\mu \mathrm{mol} \mathrm{g} \mathrm{g}^{-1}\right)$ ). All the equations are detailed in Table 3 (see also Ait Ballagh et al. (2020)). Figure 2 illustrates the biogeochemical processes of the benthic P cycle.

In the model, the $\mathrm{P}$ settling at the sediment-water interface is either associated to the organic matter by $\mathrm{C} / \mathrm{P}$ ratios for the labile and semi labile $\mathrm{OC}$ fractions or bound to $\mathrm{Fe}$-oxides 
310 (Emsley 1980; Sundby et al. 1992; Ruttenberg and Berner 1993; Slomp et al. 1996; Delaney 311 1998; Andrieux-Loyer and Aminot 2001; Slomp et al. 2004; Ruttenberg 2014). A refractory 312 part $\mathrm{P}_{\text {refrac }}\left(\mu \mathrm{mol} \mathrm{g}{ }^{-1}\right)$ which is not degraded in the sediments is added to the labile fraction 313 (Table 3, Eq. 11).

Below the sediment-water interface, organic matter mineralization releases DIP $\left(\mathrm{cm}^{-3}\right.$ 315 liquid $\mathrm{d}^{-1}$ ) in the porewaters (Table 3, Eq. 12). In the oxic zone, the DIP may diffuse to the overlying waters or be adsorbed onto sediment Fe-oxides surfaces, which leads to Fe-bound $\mathrm{P}$

317 formation $\left(\mu \mathrm{mol} \mathrm{cm}{ }^{-3}\right.$ liquid d $\left.{ }^{-1}\right)$ (Table 3, Eq. 13; (Syers et al. 1973; Froelich 1988; Fox 1990; 318 Balls 1994; Filippelli and Delaney 1996; Anschutz et al. 1998; Slomp et al. 1998; Cade-Menun 319 et al. 2019). The Fe-oxides are used as next terminal acceptors once oxygen, nitrate and manganese oxides are totally consumed (Canavan \& Slomp 2006; Krom \& Berner 1981). 321 Therefore, the adsorbed DIP is released by the dissolution of Fe-bound $\mathrm{P}\left(\mu \mathrm{mol} \mathrm{cm} \mathrm{colid} \mathrm{d}^{-1}\right)$ 322 (Table 3, Eq. 14).

In the anoxic zone, the concentrations of DIP increase through organic matter 324 mineralization and Fe-bound $\mathrm{P}$ dissolution. The porewaters are supersaturated with respect to carbo-fluorapatite $(\mathrm{DIPbw}>\mathrm{DIP}$ eq $)$, and form an authigenic mineral with $\mathrm{Ca}^{2+}$ (Ruttenberg and Berner 1993). The authigenic Ca-bound $\mathrm{P}$ (Ca-bound $\mathrm{P}_{\text {auth }}$ ) does not dissolve once it is formed, and represents a permanent sink for reactive $\mathrm{P}$ in the sediments $\left(\mu \mathrm{mol} \mathrm{cm}{ }^{-3}\right.$ liquid d $\left.\mathrm{d}^{-1}\right)$ (Table 3 ,

328 Eq. 15; Slomp et al. 1996). The coupling of the biogeochemical processes takes into account the conversion from solid units to the liquid ones $(\vartheta)$ when it is necessary and stoichiometric conversion factors (Table 3, Eq. 16- Eq. 18; Soetaert et al. 1996).

\subsubsection{Benthic budget calculation}

The steady-state benthic budgets of all simulated dissolved and solid compounds were 
334 the biogeochemical processes, burial for each state variable. Total oxic mineralization, total 335 denitrification, total anoxic mineralization, total organic $\mathrm{P}$ mineralization, total Fe-bound $\mathrm{P}$ 336 formation, total Fe-bound $\mathrm{P}$ release and total Ca-bound $\mathrm{P}$ precipitation expressed in $\mu \mathrm{mol} \mathrm{m}$ $337 \mathrm{~d}^{-1}$, are the depth-integrated values of oxic mineralization (OxicMin), denitrification (Denitrif), 338 anoxic mineralization (AnoxicMin), organic $\mathrm{P}$ mineralization ( $\mathrm{Porg}_{\min }$ ), Fe-bound $\mathrm{P}_{\text {formation}}, \mathrm{Fe}-$

339 bound $\mathrm{P}_{\text {release }}$ and Ca-bound $\mathrm{P}_{\text {precipitation }}$ depth profiles expressed in the model in $\mathrm{nmol} \mathrm{cm}^{-3} \mathrm{~d}^{-1}$, 340 respectively.

\section{Results}

\subsection{Model-data comparison of dissolved and solid phases}

The measured and simulated concentration-depth profiles of oxygen, nitrate, sulfate, 344 DIC, ammonium, ODU and total organic carbon (TOC) are presented in Figure 3 for all

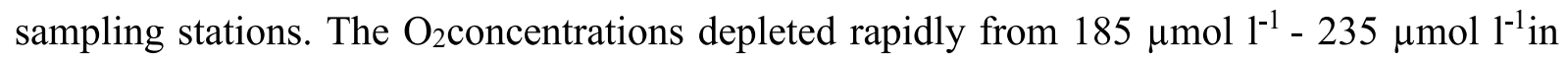
bottom waters (at stations $\mathrm{C}$ and $\mathrm{L}$, respectively; Table 5) to 0 (all stations). The $\mathrm{O}_{2}$ penetration depth into the sediment ranged from $2 \mathrm{~mm}$ in the proximal domain at station $\mathrm{Z}$ to $12.5 \mathrm{~mm}$ in the distal domain at station E, a pattern which was well represented by the model (Fig. 3).

349 Nitrate concentrations were low at all stations and showed an increase with the distance from 350 the river mouth to the adjacent continental shelf, without exceeding $15 \mu \mathrm{mol} \mathrm{l}^{-1}$ (Fig. 3). The 351 measured nitrate concentrations in the bottom waters never exceeded $3 \mu \mathrm{mol} \mathrm{l}^{-1}$ (Table 5) and 352 showed a peak below the sediment-water interface, indicating nitrification, followed by 353 denitrification, which was reproduced by the model (Fig. 3). The depth of the nitrate peak 354 increased in line with the increase of oxygen penetration from the river mouth to continental 355 shelf, an evolution that was well reproduced by the model. The measured $\mathrm{SO}_{4}{ }^{2-}$ profiles 356 highlighted a sharp decrease with sediment depth at stations $\mathrm{Z}$ and $\mathrm{A}$ in the proximal zone; the $357 \mathrm{SO}_{4}{ }^{2-}$ concentrations ranged from about $30 \mathrm{mmol} \mathrm{l}^{-1}$ in the bottom waters to concentrations 
358 below $5 \mathrm{mmol} \mathrm{l}^{-1}$ in deeper layers. The $\mathrm{SO}_{4}{ }^{2-}$ profiles showed a slighter decrease with sediment 359 depth in the prodelta and distal domains (Fig. 3-b, 3-c; stations AK, B, K, L, C and E). The 360 model was in good agreement with the $\mathrm{SO}_{4}{ }^{2-}$ measurements.

The measured and simulated DIC profiles indicated an increase with depth at all 362 stations: concentrations were extremely high in the proximal domain (around $50 \mathrm{mmol}^{-1}$ at 363 stations Z and A below $15 \mathrm{~cm}$, Fig. 3-a). DIC concentrations in porewaters at depth decreased 364 according to distance from the river mouth to about $5 \mathrm{mmol} \mathrm{l}^{-1}$ in the distal domain (Fig. 3-c, 365 station E). This pattern linked to the diagenetic intensity was also well reproduced by the model. 366 The same biogeochemical gradient was observed for the pore water $\mathrm{NH}_{4}^{+}$profiles, with 367 concentrations increasing with sediment depth at all stations. A gradient of $\mathrm{NH}_{4}{ }^{+}$concentrations 368 at sediment depth (15cm) from up to $3000 \mu \mathrm{mol} \mathrm{l}^{-1}$ (station $\mathrm{Z}$ ) until about $100 \mu \mathrm{mol} \mathrm{l}^{-1}$ (station 369 E) was visible, similarly to the DIC profiles. Therefore, a larger production of DIC and $\mathrm{NH}_{4}^{+}$ 370 was clearly observed in the proximal domain compared to the prodelta and distal domains. 371 Overall, the model was in good agreement with pore water $\mathrm{DIC}$ and $\mathrm{NH}_{4}{ }^{+}$profiles at all stations 372 (Fig. 3). The ODU concentrations (mainly $\mathrm{Fe}^{2+}$ ) displayed an increase with sediment depth, 373 with about $150 \mu \mathrm{mol} \mathrm{l}^{-1}$ close to the river mouth, but this maximum decreased in continental 374 shelf stations to less than $5 \mu \mathrm{mol} \mathrm{l}^{-1}$ (station E; Fig. 3-c). The simulated TOC profiles never 375 exceeded $2 \%$ at the sediment-water interface and showed a decrease with sediment depth at all 376 stations (Fig. 3).

Figure 4 shows the measured and simulated profiles of DIP, organic P, Fe-bound P and 378 Ca-bound P. DIP concentrations were low near the sediment-water interface, then showed an 379 increase with sediment depth. In deeper sediment layers of the proximal domain, DIP 380 concentrations were extremely high (about $250 \mu \mathrm{mol} \mathrm{l}^{-1}$ at station $\mathrm{Z}, \mathrm{A}$ and AZ). These deep 381 DIP maximum concentrations decreased with water depths and distance from the river mouth 382 until about $25 \mu \mathrm{mol} \mathrm{l}^{-1}$ at station E (Fig. 4). Overall, the model reproduced the increasing shape 
of DIP with sediment depth, except at stations Z, B and K below $10 \mathrm{~cm}$ depth (Fig. 3). The DIP

384 evolution followed a similar pattern as DIC and $\mathrm{NH}_{4}{ }^{+}$for all stations. The measured organic $\mathrm{P}$ 385 profiles never exceeded $10 \mu \mathrm{mol} \mathrm{g}^{-1}$ at the sediment-water interface at all stations. Organic $\mathrm{P}$ 386 showed a slight decrease with sediment depth and showed a generally constant concentration 387 offshore. Stations $\mathrm{Z}$ and A displayed a larger spread of organic P values with sediment depth. 388 The model showed a good agreement with average measurements for this phase but showed a 389 large gradient near the sediment-water interface (Fig. 4). Similarly, the observed Fe-bound P 390 concentrations at stations $\mathrm{A}, \mathrm{Z}$ and $\mathrm{AZ}$ showed dispersed values, while the model reproduced 391 the average Fe-bound P concentrations and showed a slight decrease with sediment depth (Fig. 392 4). Concerning the other stations, the average Fe-bound $\mathrm{P}$ concentrations were well represented 393 by the model (Fig. 4). A similar pattern was found for Ca-bound $\mathrm{P}_{\text {auth }}$ concentrations and 394 showed also dispersed values in stations A, Z and AZ. This phase showed very consistent values 395 at the profile scale and between profiles at all stations from the river mouth to the continental 396 shelf, which was overall reproduced by the model (Fig. 4).

\subsection{Boundary conditions and model parameters}

The fixed parameters of the model listed in Table 4 were ammonium adsorption coefficient $\left(\mathrm{NH}_{3 \mathrm{Ads}}\right)$, maximum oxidation of ODU (roDUox $)$, nitrification rate constant ( $\left.\mathrm{r}_{\text {nit }}\right)$, halfsaturation constants for $\mathrm{O}_{2}$ limitation for oxic mineralization (Kso2oxic) and nitrification

401 (KsO2nitri), nitrate limitation for nitrate reduction $\left(\mathrm{Ks}_{\mathrm{NO} 3 \text { denit }}\right), \mathrm{O}_{2}$ limitation for the oxidation of reduced substances (KsO2oduox $), \mathrm{O}_{2}$ inhibition for nitrate reduction (KinO2denit) and anoxic mineralization (Kin $\left.{ }_{\mathrm{O} 2 \mathrm{anox}}\right)$, nitrate inhibition for anoxic mineralization ( $\mathrm{Kin}_{\mathrm{NO} 3 a n o x}$ ), sulfate

404 limitation for anoxic mineralization $\left(\mathrm{Ks}_{\mathrm{SO}} 4\right)$ and finally the $\mathrm{C} / \mathrm{N}$ and $\mathrm{C} / \mathrm{P}$ fixed for labile and 405 semi-labile fractions of organic carbon for all the sampling stations (Table 4). The $\mathrm{C} / \mathrm{N}_{\text {fast }}$ and $\mathrm{C} / \mathrm{N}_{\text {slow }}$ were fixed to 7.1 (Pastor et al. 2011) and 10 (Khalil et al. 2018), respectively. The C/P 
ratio was fixed by assuming that $\mathrm{N} / \mathrm{P}$ was equal to 16 . Therefore, the estimated $\mathrm{C} / \mathrm{P}$ for labile

408 fraction $\left(\mathrm{C} / \mathrm{P}_{\text {fast }}\right)$ was averaged to 114 , while the $\mathrm{C} / \mathrm{P}$ for semi-labile fraction $\left(\mathrm{C} / \mathrm{P}_{\text {slow }}\right)$ was 160 .

409 It is noteworthy that because the proportion of the labile fraction increases offshore (from $50 \%$

410 to $75 \%$ ), the overall $\mathrm{C} / \mathrm{P}$ ratio decreases as well from 137 in the proximal zone to 126 in the

411 distal zone which is consistent with the aquatic nature of the organic matter degraded in these

412 sediments.

Table 5 includes the parameters that were measured at each station. The bottom water 414 temperature ranged between $14.7^{\circ} \mathrm{C}$ (at station $\mathrm{C}$ ) and $20^{\circ} \mathrm{C}$ (at station $\mathrm{AZ}$ ), which is typical of the area at this season. Salinity varied between 37.8 at station A and AZ and 38.5 at station

$\mathrm{K}$ (Table 5). The bottom water concentrations of all dissolved phases did not follow a spatial 417 pattern (Table 5). The bottom water concentrations of $\mathrm{NO}_{3}{ }^{-}, \mathrm{NH}_{4}{ }^{+}$and ODU were low for all 418 stations. The $\mathrm{SO}_{4}{ }^{2-}$ concentrations were nearly constant in bottom waters and close to $30 \mathrm{mmol}$ $4191^{-1}$ at all stations (Table 5). The porosity at surface sediment and at depth were lowest in station $\mathrm{K}(0.76$ and 0.58 , respectively), and highest in station $\mathrm{C}(0.86$ and 0.64 , respectively). The sedimentation rates adopted for this modelling study were obtained from literature (Charmasson et al. 1998; Radakovitch et al. 1999; Miralles et al. 2005; Lansard et al. 2007), ranging from 10 $\mathrm{cm} \mathrm{y}^{-1}$ in proximal domain, to $0.1 \mathrm{~cm} \mathrm{y}^{-1}$ in distal domain (Pastor et al. 2011).

The parameters estimated by fitting the model to the data are listed in Table 6. The reactive $\mathrm{OC}$ flux $\left(\mathrm{OC}_{\text {flux }}\right)$ followed a spatial pattern and decreased from $160 \mathrm{mmol} \mathrm{m} \mathrm{d}^{-1}$ at station $\mathrm{Z}$ (the river mouth) to $10 \mathrm{mmol} \mathrm{m}^{-2} \mathrm{~d}^{-1}$ at station $\mathrm{E}$ on the continental shelf. The first427 order decay rate constants for labile fraction of OC $\left(\mathrm{R}_{\text {fast }}\right)$ showed a clear increase with distance 428 to the continental shelf $\left(0.06 \mathrm{~d}^{-1}\right.$ at station $\mathrm{Z}$ to $0.2 \mathrm{~d}^{-1}$ at stations $\left.\mathrm{B}, \mathrm{K}, \mathrm{L}, \mathrm{C}, \mathrm{E}\right)$. Contrarily, the 429 first-order decay rate constants of the semi-labile fraction $\left(\mathrm{R}_{\text {slow }}\right)$ decreased with distance to the 430 river from $0.0035 \mathrm{~d}^{-1}$ at station $\mathrm{Z}$ to $0.0002 \mathrm{~d}^{-1}$ at stations $\mathrm{B}$ and $\mathrm{C}$ (Table 6). The labile OC 431 represented an important proportion of OC $\left(\mathrm{P}_{\text {fast }}\right)$ that increased from $50 \%$ near the river mouth 
432 (stations $\mathrm{Z}$ and A) to $75 \%$ on the continental shelf. The refractory carbon varied between 0.9

433 and $1.4 \%$ (Table 6). The proportion of ODU deposition $\left(\mathrm{P}_{\mathrm{depo}}\right)$ ranged between $90 \%$ and $99 \%$.

434 The bioturbation layer thickness $\left(\mathrm{x}_{\mathrm{b}}\right)$ increased from $5 \mathrm{~cm}$ in stations $\mathrm{A}, \mathrm{Z}$ and $\mathrm{AZ}$, to $10 \mathrm{~cm}$ for 435 other stations, while the bioturbation coefficient $\left(\mathrm{D}_{\mathrm{b} 0}\right)$ was relatively invariant (from $0.01 \mathrm{~cm}^{2}$ $436 \mathrm{~d}^{-1}$ to $\left.0.015 \mathrm{~cm}^{2} \mathrm{~d}^{-1}\right)$. The bioirrigation at the sediment surface $\left(\alpha_{\text {irro }}\right)$ was needed for all stations 437 but did not indicate a clear spatial trend according to the distance from the Rhône mouth $(0.05$ $\left.438-0.2 \mathrm{~d}^{-1}\right)$, with bioirrigation depths $\left(\mathrm{x}_{\text {irr }}\right)$ ranging between $6 \mathrm{~cm}$ and $14.5 \mathrm{~cm}$ of depth (Table 6).

The Fe-bound $\mathrm{P}$ fluxes at the sediment-water interface (Fe-bound $\mathrm{P}_{\text {flux }}$ ) decreased offshore with values as high as $730 \mu \mathrm{mol} \mathrm{m} \mathrm{m}^{-2} \mathrm{~d}^{-1}$ at station $\mathrm{Z}$ and decreased to $10 \mu \mathrm{mol} \mathrm{m} \mathrm{m}^{-2} \mathrm{~d}^{-1}$

441 at stations $\mathrm{C}$ and $\mathrm{E}$. The Fe-bound $\mathrm{P}$ formation rate constants ( $\left.\mathrm{R}_{\mathrm{Fe}-\text { bound Pform }}\right)$ were $0.8 \mathrm{~d}^{-1}$ at all 442 stations, except for stations $\mathrm{C}$ and $\mathrm{E}$ where they were only $0.1 \mathrm{~d}^{-1}$. Concerning the Fe-bound $\mathrm{P}$ release, the rate constants $\left(\mathrm{R}_{\mathrm{Fe}-\text { bound Prel }}\right)$ were similar at all stations between $0.0005 \mathrm{~d}^{-1}$ (at stations $\mathrm{B}$ and $\mathrm{K}$ ) and $0.0008 \mathrm{~d}^{-1}$ (at the other stations; Table 6). The Fe-bound $\mathrm{P}$ asymptotic concentrations (Fe-bound $\mathrm{P}_{\text {asymp}}$ ) ranged between $2 \mu \mathrm{mol} \mathrm{g}^{-1}$ (at station $\mathrm{A}$ ) and $4 \mu \mathrm{mol} \mathrm{g}^{-1}$ (at

446 station $\mathrm{C})$. The Ca-bound $\mathrm{P}$ precipitation rate constants ( $\left.\mathrm{R}_{\text {Ca-bound Pprecip }}\right)$ ranged between 0.002 $447 \mathrm{~d}^{-1}$ (stations K and C) and $0.006 \mathrm{~d}^{-1}$ (stations $\mathrm{Z}$ and L) (Table 6). Inherited concentrations of Cabound $\mathrm{P}\left(\mathrm{Ca}-\right.$ bound $\mathrm{P}_{\text {her }}$ ) were between $3.6 \mu \mathrm{mol} \mathrm{g} \mathrm{g}^{-1}$ and $5.3 \mu \mathrm{mol} \mathrm{g}$.

\section{Discussion}

The application of the model to the dataset from sediments on all stations (from $\mathrm{Z}$ to $\mathrm{E}$ )

451 along the Rhône River prodelta allowed quantifying total organic matter mineralization rates 452 and calculating the contribution of different diagenetic pathways to the mineralization 453 processes. Moreover, the addition of the benthic P cycle allowed identifying the sources and 454 sinks of internally produced DIP and calculating sedimentary P budgets in proximal, prodelta and distal domains. 


\subsection{Spatial variability of organic matter mineralization}

\subsubsection{The organic matter properties}

The $\mathrm{OC}$ fluxes $\left(\mathrm{OC}_{\text {flux }}\right)$ ranged between 160 and $10 \mathrm{mmol} \mathrm{m} \mathrm{m}^{-2}($ Fig. 5) and were characteristic of organic-rich ecosystems (Rabouille et al. 2008). They were similar to the obtained OC fluxes for the same stations at the Rhône River prodelta by Pastor et al. (2011). Moreover, the OC fluxes decreased exponentially as a function of distance from the Rhône River mouth (Fig. 5). This decrease was already observed by Cathalot et al. (2010) for the oxygen diffusive fluxes. During flood events, occurring mostly in fall-winter, the majority of organic-rich particulate inputs from the Rhône River are accumulated in the proximal and prodelta domains. Therefore, these areas are characterized by large OC mineralization rates during spring (Lansard et al. 2009; Cathalot et al. 2010; Pastor et al. 2011; Rassmann et al. 2016). This is also evidenced in the results by complete removal of sulfate during sulfate reduction and the intense production of DIC especially in the proximal domain.

In front of the Rhône River mouth, Rassmann et al. (2016; 2020) showed that pore waters were supersaturated with $\mathrm{Ca}^{2+}$, preventing carbonate dissolution in these deltaic sediments. As a consequence, the DIC was mainly produced by OC mineralization processes (i.e. bacterial respiration). The obtained fluxes $\left(10-160 \mathrm{mmol} \mathrm{m}^{-2} \mathrm{~d}^{-1}\right)$ were in the same range as those from the Louisiana shelf $\left(35 \mathrm{mmol} \mathrm{m}^{-2} \mathrm{~d}^{-1}\right.$; Morse and Eldridge, 2007), although higher in the proximal domain. They were higher also compared to the Guadalquivir River mouth (Ferrón et al. 2009) and the Po River (Hammond 1999).

In addition to refractory carbon, the model takes into account two fractions of organic matter with variable reactivities, the labile and semi-labile fractions. Each labile and semi-labile fraction has a first-order decay rate constant $\left(\mathrm{R}_{\text {fast }}\right.$ and $\mathrm{R}_{\text {slow, }}$, respectively; Soetaert et al. 1996), while the proportion of labile OC $\left(\mathrm{P}_{\text {fast }}\right)$ determines the relative abundance of both fractions in the OC inputs. The reactive compound was the dominant fraction in the organic carbon input 
$481\left(\mathrm{C}_{\mathrm{org}}\right)$ as it increased from $50 \%$ in the proximal zone to $75 \%$ in the continental shelf (Table 6 ),

482 being negatively correlated to the OC fluxes as has been already mentioned in Pastor et al 483 (2011). The first-order decay rate constant of the labile $\mathrm{OM}$ fraction $\left(\mathrm{R}_{\text {fast }}\right)$ was higher in the prodelta and distal domains compared to the proximal domain and increased with distance 485 offshore from $0.06 \mathrm{~d}^{-1}$ at the river mouth to $0.2 \mathrm{~d}^{-1}$ on the continental shelf (Fig. 6a) which 486 indicated a progressive increase in lability and proportion of labile organic matter with the 487 distance offshore. The rate constants in the proximal zone (0.06 to $\left.0.15 \mathrm{~d}^{-1}\right)$ were slightly higher 488 than those calculated for the Mississippi delta and the Louisiana shelf $\left(0.02-0.05 \mathrm{~d}^{-1}\right.$; Morse and Eldridge, 2007). However, the rate constants calculated for the continental shelf were in the 490 same range as the eutrophic Scheldt estuary $\left(0.15 \mathrm{~d}^{-1}\right.$; Hofmann et al. 2008) and the Thau lagoon $491\left(0.1 \mathrm{~d}^{-1}\right)$, which are characterized by labile organic matter from phytoplankton and macrophyte 492 debris (Dedieu et al. 2007).

The first-order decay rate constant of the semi-labile OM fraction $\left(\mathrm{R}_{\text {slow }}\right)$ decreased with 494 distance from the Rhône River mouth to the continental shelf by a factor of $10(0.0035$ to 0.0002 $495 \mathrm{~d}^{-1}$, respectively; Fig. 6b). This could be related to the supply of older and less reactive material

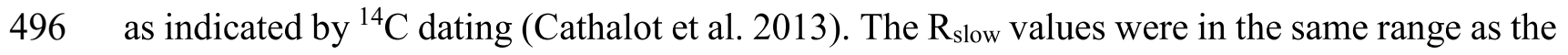
497 values from the eutrophic environments, such as Scheldt estuary $\left(0.002 \mathrm{~d}^{-1}\right.$; Hofmann et al. 498 2008) and the Thau lagoon (0.001 d $\mathrm{d}^{-1}$; Dedieu et al. 2007). This trend matched with the results 499 of Pastor et al. (2011) and highlighted that the mix of labile and semi-labile organic matter in 500 the proximal and prodelta domains contained essentially terrestrial fine and coarse organic 501 matter including a small proportion of riverine organic matter (Dumoulin et al. 2018). At the 502 same time, the sediments in the distal domains probably receive labile marine organic matter 503 (Pozzato et al. 2018) which is entirely mineralized together with aged terrestrial organic 504 particles (Lansard et al. 2009). 
The $\mathrm{R}_{\text {fast }}, \mathrm{R}_{\text {slow }}$ and $\mathrm{P}_{\text {fast }}$ values highlighted that the terrestrial organic matter in the

506 proximal domain, was composed of fine and coarse continental material rich in organics

507 (Cathalot et al. 2013). It was less reactive than those at other stations offshore probably due to 508 prior degradation during transport or storage on land. Stations offshore receive a larger 509 proportion of marine organic material such as phytoplankton (Pastor et al. 2011). This evolution 510 is confirmed by the results obtained using $\delta^{13} \mathrm{C}_{\mathrm{OC}}$ by Lansard et al. (2009). $\delta^{13} \mathrm{C}_{\mathrm{OC}}$ varied from $511-26.8 \%$ in the proximal domain sediments to $-23.9 \%$ on the shelf, showing a significant 512 increase in the distal domain, linked to the limited dispersal of terrestrial organic matter on the continental shelf. The limited transport of terrestrial organic matter led to the highest values of

$514 \mathrm{R}_{\text {fast }}$ with distance from the River mouth linked to the increase of marine material proportion 515 (Fig. 6a).

\subsubsection{Organic matter mineralization processes}

The decreasing mineralization rates of organic matter from the proximal to distal domain was reflected in the penetration depths of oxygen that were less than $2 \mathrm{~mm}$ at stations $\mathrm{A}$ or $\mathrm{Z}$ while they reached $12.5 \mathrm{~mm}$ in the distal domain (Cathalot et al. 2010; Rassmann et al. 2016). At these stations, the large increase of DIC production and the high consumption of sulfate indicated the large mineralization of reactive organic matter (Fig. 3).

The pore water $\mathrm{NH}_{4}{ }^{+}$, DIC, and DIP were indicators of organic matter mineralization, and their concentrations increased as function of sediment depth (Fig. 3; Berg et al. 2003). Overall, the prodelta stations showed lower concentrations of these compounds in deep sediments compared to the proximal domain (e.g. the $\mathrm{NH}_{4}{ }^{+}$with $300-1000 \mu \mathrm{mol}^{-1}$ and 2000$3500 \mu \mathrm{mol} \mathrm{l}^{-1}$, respectively) but were higher than the distal domain $\left(200-500 \mu \mathrm{mol} \mathrm{l}^{-1}\right)$. The same pattern was shown by the other components (Fig. 3). The observed decrease of asymptotic 528 concentrations of DIC, $\mathrm{NH}_{4}{ }^{+}$and DIP with distance to the shore was related to the decrease of 529 OC mineralization rates in these areas, causing the decrease of anoxic mineralization. This is 
well reflected in Table 6 where OC flux represents the metabolizable organic matter deposition which, in the model calculation, is completely mineralized in surficial sediments. The values of this "integrated mineralization" varies from over $100 \mathrm{mmol} \mathrm{C} \mathrm{m}^{-2} \mathrm{~d}^{-1}$ in the proximal zone to $10 \mathrm{mmol} \mathrm{C} \mathrm{m} \mathrm{d}^{-1}$ on the distal shelf, with a gradual decrease over the prodelta.

In the proximal domain, and after the total consumption of $\mathrm{O}_{2}$ and $\mathrm{NO}_{3}^{-}$, the ODU mainly consisted of dissolved $\mathrm{Fe}^{2+}$, as $\mathrm{H}_{2} \mathrm{~S}$ is very low (Rassmann et al. 2020). The ODU showed an increase of concentrations with sediment depth, corresponding to the Fe-bound P decrease (Fig. 4). This indicated a production of dissolved Fe and a potential release of DIP through the reductive dissolution of Fe-oxides, used as a terminal electron acceptor in the anoxic zone of sediments (Krom and Berner 1981; Canavan and Slomp 2006). This Fe-bound $\mathrm{P}$ decrease was less important in prodelta and distal domains, as shown by rather constant Febound P profiles with depth, which indicated that the released DIP in the sediments mainly originated from the organic matter release without, or with a minor contribution of net Fe-bound P release (Fig. 4).

Overall, the model calculations showed that oxic mineralization followed a spatial pattern along the biogeochemical gradient, increasing its contribution to the total mineralization from $13.7 \%$ (station A, proximal domain) to $80 \%$ (station E, the distal domain; Fig. 7). The oxic mineralization contribution showed the same pattern as Pastor et al. (2011) and was in the same range $(8-67 \%)$. The oxygen below the sediment-water interface was used also for the reoxidation of $\mathrm{NH}_{4}{ }^{+}$and the reduced substances that were produced in the anoxic zone. However, the nitrification process was not very important in the Rhône prodelta sediments, and only a small fraction of ODU was reoxidized, since more than $90 \%$ of ODU was buried at depth ( $\mathrm{p}_{\text {depo, }}$ Table 6). Therefore, the main process responsible for oxygen consumption was oxic mineralization. The denitrification represented the smallest contribution compared to the other mineralization pathways ( 0.7 to $3.7 \%$ ) and showed an increase from proximal to distal domains 
(Fig. 7). This low contribution was due to the fact that denitrified $\mathrm{NO}_{3}{ }^{-}$originated only from

556 nitrification below the sediment-water interface, due to the low concentration of $\mathrm{NO}_{3}{ }^{-}$in bottom waters (Table 5). Anoxic mineralization was related to the Mn-oxides, Fe-oxides and sulfate reduction in the anoxic zone. It exhibited a clear spatial gradient, accounting for more than $85 \%$ of total mineralization near the river mouth, decreasing to $16 \%$ near the continental shelf (Fig. 7). Sensitivity analysis of the model showed that the variations of the sedimentation rates in the Rhône proximal and prodelta domains do not impact significantly the mineralization pathways contributions. Indeed, an increase by a factor of 10 of the sedimentation rates (from 1 to $10 \mathrm{~cm}$ $\mathrm{y}^{-1}$ in the proximal zone and 0.1 to $1 \mathrm{~cm} \mathrm{y}^{-1}$ for the prodelta domain) induced slightly lower contribution of oxic mineralization (from 18 to $14 \%$ of the total mineralization) in the proximal domain and was negligible in the prodelta domain.

The model showed a decreasing loss of ODU by burial from $99 \%$ at station $\mathrm{Z}$ to $90 \%$ at station $\mathrm{C}$ (Table 6). The ODU deposition highlighted a loss of reduced products of mineralization at deeper depths as solid substances, such as pyrite (Berner 1970; Soetaert et al. 1996). Similarly, high removal rates were found previously by Pastor et al. (2011) and Rassmann et al. (2020) in the Rhône River prodelta.

\subsection{Benthic $P$ transformation along the Rhône River prodelta}

At the proximal stations, DIP concentrations showed an increase with sediment depth until a maximum of $300 \mu \mathrm{mol} 1^{-1}$. The DIP concentrations was larger compared with concentrations obtained by Rassmann et al. (2020) for the same stations (50-160 $\left.\mu \mathrm{mol}^{-1}\right)$. This was probably linked to the intensity of OC inputs from 2015 (Rassmann et al. 2020) to 2018

576 (this study). As pointed out in the literature, the secondary conversion of Fe-oxides to FeS certainly contributed to the net release of adsorbed DIP on Fe-oxides with sediment depth (Anschutz et al. 1998). Indeed, Rassmann et al. (2020) described a clear precipitation of FeS at 
the proximal stations as shown by the spatial pattern of solid FeS, decreasing from the proximal domain to the adjacent continental shelf sediments. Both the increase of DIP concentrations and decrease of Fe-bound $\mathrm{P}$ with sediment depth in the proximal and prodelta zones accompanied a slight increase of Ca-bound $\mathrm{P}$ with depth, characterized by dispersed values of measurements (Fig. 4). The high DIP concentrations in porewaters likely contributed to the precipitation of Ca-bound $\mathrm{P}_{\text {auth }}$ (Fig. 4). Despite the decrease of OC fluxes to the seafloor and thus of organic $\mathrm{P}$, the Fe-bound $\mathrm{P}$ and the Ca-bound $\mathrm{P}$ concentrations were almost similar at the sediment-water interface in the proximal, prodelta and distal domains (Figs. 3 and 4). This can probably be related to a compensation of flux versus sedimentation, as both decrease at a similar rate from the River mouth to offshore.

\subsubsection{Sources of pore water DIP}

The organic $\mathrm{P}$ input to the sediment was calculated using the organic $\mathrm{C}$ fluxes and the $\mathrm{C} / \mathrm{P}_{\text {fast }}$ and $\mathrm{C} / \mathrm{P}_{\text {slow }}$ assumed in this study (Table 4). The obtained integrated rates of organic $\mathrm{P}$ mineralization, extremely high at the River mouth (1196 $\mu \mathrm{mol} \mathrm{m} \mathrm{m}^{-2} \mathrm{~d}^{-1}$; Fig. 8), were characteristic of organic-rich ecosystems. Their decrease from the proximal to the distal domain (1196 to $81 \mu \mathrm{mol} \mathrm{m} \mathrm{m}^{-2} \mathrm{~d}^{-1}$; Fig. 8), was linked to the decrease of organic matter inputs (Pastor et al. 2011).The values obtained from the Rhône prodelta sediments were higher than the integrated rates of organic P mineralization from the eutrophic Elorn and Aulne estuaries (262 - 757 and $172-414 \mu \mathrm{mol} \mathrm{m}^{-2} \mathrm{~d}^{-1}$, respectively; Ait Ballagh et al. 2020). Figure 8 shows that the organic P mineralization represented the main source by up to $90 \%$ of the total DIP production, while the net Fe-bound P release had a minor contribution in benthic DIP production at all stations ( $\mathrm{Z}$ to $\mathrm{E})$.

Concerning the Fe-bound P fluxes deposited at the sediment-water interface (Fe-bound $\left.\mathrm{P}_{\text {flux }}\right)$, Table 6 and Figure 8 highlighted their importance in the proximal domain $(730 \mu \mathrm{mol} \mathrm{m}-$ ${ }^{2} \mathrm{~d}^{-1}$ at station $\mathrm{AZ}$ ), which were more than 10 times higher in the prodelta and distal domains 
604 (82 and $10 \mu \mathrm{mol} \mathrm{m}^{-2} \mathrm{~d}^{-1}$ at stations B and E, respectively). The Fe-bound P fluxes in the distal 605 domain were similar to the fluxes from Vilaine Bay (4 - $25 \mu \mathrm{mol} \mathrm{m} \mathrm{m}^{-2} \mathrm{~d}^{-1}$; Ratmaya, 2018), due 606 to the similarity of sedimentation regimes at the sampling stations of the distal zone $\left(0.1 \mathrm{~cm} \mathrm{yr}^{-}\right.$ $\left.60{ }^{1}\right)$ and the Vilaine Bay $\left(0.2 \mathrm{~cm} \mathrm{yr}^{-1}\right.$; Ratmaya, 2018).

Except at station A (Fig. 9), the model indicated that the formation of Fe-bound $\mathrm{P}$ in the oxic zone and its release below were very similar along the Rhône River prodelta. This indicated

610 that, at all stations, Fe-bound P acted as a temporary sink for DIP in the oxic zone, which was 611 thereafter released in the anoxic zone. Therefore, Fe-bound P acted as a shuttle between organic $612 \mathrm{P}$ mineralization and Ca-bound $\mathrm{P}_{\text {auth }}$ precipitation (sink-switching) along the Rhône River 613 prodelta (Ruttenberg and Berner 1993; Slomp et al. 1998; Kraal et al. 2015).

\subsubsection{Consumption/export of internally produced DIP}

$\mathrm{P}$ release was essentially lost by recycling to the overlying waters rather than burial through

617 Ca-bound $\mathrm{P}_{\text {auth }}$ formation. Figure 10 indicated that the sum of both processes, in terms of DIP 618 consumption/export fluxes, decreased from the river mouth to the continental shelf similarly to 619 the organic matter mineralization. A difference by a factor of 3 was observed between the 620 proximal and the prodelta domains while a factor of 10 was calculated between the proximal 621 and the distal domains. In the prodelta and distal domains, the recycled DIP accounted for up 622 to $90 \%$ of total DIP losses, while the burial of reactive $\mathrm{P}$ as Ca-bound $\mathrm{P}_{\text {auth }}$ form was higher in 623 the proximal domain but never exceeded $28 \%$ of the total DIP loss (Fig. 10). to continental shelf (931 to $74 \mu \mathrm{mol} \mathrm{m} \mathrm{m}^{-2}$ ) and occurred mainly through molecular diffusion $626(>70 \%)$ at all stations, while bioirrigation process accounted for a minor part. These recycled 627 DIP fluxes to the overlying waters were in the same range as those from the Elorn and Aulne 
628 estuaries ( $85-738 \mu \mathrm{mol} \mathrm{m} \mathrm{d}^{-1}$; Ait Ballagh et al. 2020), the Haringvliet lake (370 $\mu \mathrm{mol} \mathrm{m}^{-2}$ $629 \mathrm{~d}^{-1}$; Canavan and Slomp, 2006) and those from the Gulf of Finland $0-1032 \mu \mathrm{mol} \mathrm{m}^{-2} \mathrm{~d}^{-1}$

630 (Lehtoranta et al. 2017). The eutrophic Haringvliet lake, the Vilaine bay, the Elorn and Aulne 631 estuaries were similar to the Rhône River prodelta in terms of the role of organic P 632 mineralization as the main benthic DIP source, unlike the Gulf of Finland, where the DIP 633 release mostly originated from the Fe-bound P release (Canavan and Slomp 2006; Lehtoranta 634 et al. 2017).

\subsubsection{Sedimentary biogeochemical $P$ budgets}

Figure 11 represents vertically integrated P budgets for 3 selected stations, 1 from each domain: the proximal (station A), prodelta (station K) and distal (station E) domains. For these budgets the benthic P processes were integrated over the sedimentary column of each sampling station. Overall, it is clear that DIP was mainly released by organic P mineralization, as it was the main source of DIP the Rhône prodelta sediments. However, this intensity was enhanced by the Fe-bound $\mathrm{P}$ phase, with minor contribution of net Fe-bound $\mathrm{P}$ release. As the organic $\mathrm{P}$ mineralization fluxes decreased from the proximal (1004- $1196 \mu \mathrm{mol} \mathrm{m}^{-2} \mathrm{~d}^{-1}$; Fig. 11, station A) to the distal domain (113 and $81 \mu \mathrm{mol} \mathrm{m} \mathrm{m}^{-2} \mathrm{~d}^{-1}$, station E), the Fe-bound $\mathrm{P}$ fluxes also decreased by a factor of 50 between the river mouth and offshore in relation with the decrease of the river material deposition offshore. Therefore, the iron related $\mathrm{P}$ cycle decreased in intensity towards the shelf with an overall minor contribution in the proximal zone ( $8-81 \mu \mathrm{mol}$ $\mathrm{m}^{-2} \mathrm{~d}^{-1}$ ) and no net Fe-bound P release contribution in the distal domain (Fig. 11). overlying waters by molecular diffusion at all domains. A significant sink was calculated as

650 Ca-bound $\mathrm{P}_{\text {auth }}$ burial in the proximal zone (Fig. 11, station A) with a rapid levelling off offshore 651 as the production of DIP in the sediment decreased. Sensitivity tests showed that uncertainty 652 on the sedimentation rates may impact the calculated rate of DIP recycling to the water column. 
653 Indeed, increasing sedimentation rates by a factor of 10 (from 1 to $10 \mathrm{~cm} \mathrm{y}^{-1}$ in the proximal

654 zone) decreased DIP production in the sediment essentially by lowering the contribution of Fe-

655 bound P dissolution to DIP, and contributed to lower overall DIP flux to the water column ($65640 \%$ ). This increase of sedimentation rate also induced an increase of burial as Ca-bound P $657(+34 \%)$ in the proximal domain. Furthermore, these sensitivity tests showed that the C/P ratios 658 which control the input of organic $\mathrm{P}$ to the sediment have an influence on the mass balance of 659 the $\mathrm{P}$ cycle. An increase of the $\mathrm{C} / \mathrm{P}$ of semi-labile organic matter from 160 (used in this study) 660 to 200 would decrease the recycling flux by $20 \%$ in the proximal domain, essentially because 661 of the lower flux of organic P deposited in the sediment. Ca-bound P burial would also be 662 lowered by $15 \%$ because of the decreased DIP availability. Lower variations were calculated 663 for the prodelta domain with less than $10 \%$ variation of DIP recycling and Ca-bound P burial 664 for similar variations of $\mathrm{C} / \mathrm{P}$ in the semi-labile fraction. The change of $\mathrm{C} / \mathrm{P}$ for the labile fraction 665 (from 114, adopted in this study, to 100) would have a lower impact on the P mass balance with 666 decreases of 9\% for DIP recycling and 3\% for Ca-bound P burial.

\subsection{The $P$ budgets at a deltaic scale}

In order to assess the contribution of the Rhône River prodelta as a source/sink of DIP 669 to or from the Mediterranean Sea, the P budgets (recycling/burial) along the Rhône River 670 prodelta were calculated. For that purpose, we averaged the benthic DIP fluxes and authigenic 671 Ca-bound P burial fluxes obtained using the model-data approach for each zone of interest 672 (proximal, prodelta and continental shelf-distal zones). As these zones were rather 673 homogeneous regarding the benthic DIP fluxes and Ca-bound $\mathrm{P}_{\text {auth }}$ burial $( \pm 20 \%$ standard 674 variation, see Fig. 10) compared to the overall variation between the zones (one order of 675 magnitude between proximal and distal zones, Fig. 10), averaging did not bring significant bias 676 in the final calculations. Surface areas of the proximal, prodelta and distal domains (Table 7) 
677 were adopted from Lansard et al. (2009) in agreement with the Thiessen's polygon method, 678 used in Cathalot (2008).

By using these surface areas, we obtained the total benthic DIP fluxes (a source to the water) and the sink due to precipitated Ca-bound P burial in the sediments of the Rhône River 681 prodelta and its adjacent continental shelf. These fluxes were then compared to the riverine DIP 682 discharge. According to Malagó et al. (2019), the Rhône River delivered 1465 tons DIP $\mathrm{yr}^{-1}$ to the Mediterranean Sea from 2003 to 2007, whereas Ludwig et al. (2009) estimated a discharge of 2750 tons DIP $\mathrm{yr}^{-1}$, in agreement with direct measurements by Moutin et al. (1998). These separate estimations varied by a factor of 2 which could be related to the decrease of $\mathrm{P}$ inputs to the rivers from the $1990 \mathrm{~s}-2000$ s to the end of the 2010s. It may also be due to differences in assumptions for the calculations. It is out of the scope of this paper to further discuss these issues and we used the two values for bracketing our estimates of the prodelta contribution in the DIP source and sink.

As can be seen from Table 7, the DIP fluxes recycled from the sediment accounts for $691 \quad 19-35 \%$ of the riverine discharge input of DIP which indicates that this source could represent an additional source corresponding to $25 \%$ of the Rhône input. We propose here that it can be considered as an additional source of DIP to the Mediterranean Sea since the largest part of this

694 benthic flux originates from the recycling of organic P of terrestrial origin. These calculated 695 proportions surely contain uncertainties on some assumptions such as the DIP inputs and the 696 extrapolation of summer values of P budgets over the year. However, the calculation at the 697 deltaic scale over the entire year was necessary in order to compare the sediment source to the 698 river input. These calculations are important because the sediments contribution was substantial 699 compared to riverine inputs, especially near the river mouth and no estimations were available 700 before this study for the Rhône River prodelta. Finally, we estimate that the obtained DIP flux 
701 from the sediment may be overestimated by less than one third due to the extrapolation over the year.

In the proximal and prodelta zones, it corresponds to the recycling of terrestrial organic matter (Cathalot et al. 2013) and is not related to internal recycling of marine (or deltaic) production based on riverine DIP input. It thus constitutes a real addition to the DIP input from the Rhône River. This is probably less true for the continental shelf sediments (33\% of benthic DIP recycling) where marine organic matter produced by DIP originating from the Rhône River is partly recycled in surface sediments, therefore not totally contributing as an additional source. Considering that, the $25 \%$ addition to the riverine flux by benthic recycling of organic $\mathrm{P}$ can be seen as an upper boundary. to DIP production by mineralization in the sediment (see Fig. 11), it does not constitute a true

714 sink of DIP delivered from the Rhône River. Indeed, as stated above, most of the mineralized organic $\mathrm{P}$ in the proximal and prodelta zones originates from the continent and is independent of the DIP source from the Rhône River. Only the share of Ca-bound $\mathrm{P}_{\text {auth }}$ burial in continental shelf sediments can be considered a sink of DIP originating from the Rhône River as organic matter mineralized in these sediments is of marine origin based on nutrients from the Rhône River. As it represents only $20 \%$ of the total Ca-bound $\mathrm{P}_{\text {auth }}$ burial, it can be considered that a very limited fraction of the DIP input by the river $(<1 \%)$ is precipitated as Ca-bound $\mathrm{P}$ and buried in sediments.

\section{Conclusion}


In order to gain new insights about organic matter and phosphorus transformation in the sediments along the Mediterranean Rhône River prodelta, we used a modelling approach based on an early diagenetic model (OMEXDIA) coupled to the dataset from proximal, prodelta and distal domains. The model application highlighted the intensity of mineralization processes from the Rhône River mouth to the adjacent continental shelf. This intensity was mainly driven by high deposition of $\mathrm{OC}$ in the sediments, as a characteristic of organic-rich ecosystems, with a large proportion of terrestrial organic matter, hence providing a biogeochemical gradient. The combined model parameters indicated that the OC fluxes to the seafloor led to the increase of oxic mineralization rates and reduction of anoxic mineralization rates contribution, as a function of distance from the Rhône River mouth. According to the model, the anoxic mineralization contributed to the large concentrations of mineralization products at the sediment depth such as DIC, DIP and $\mathrm{NH}_{4}{ }^{+}$, especially in the proximal domain. Our modelling approach was extended to include the benthic P cycle along the Rhône River prodelta. It showed that there was an intense production of porewater DIP, mainly by organic $\mathrm{P}$ mineralization. The Fe-bound $\mathrm{P}$ was a small net source of DIP in the proximal zone and was negligible in the prodelta and distal domains, while this phase had a key role in trapping and transferring DIP in sediment, promoting the Ca-bound $\mathrm{P}$ precipitation in anoxic sediments in the proximal domain. However, the sediments along the Rhône River prodelta acted mainly as secondary source of DIP to the overlying waters, corresponding to a maximum of $25 \%$ of the riverine input, as only a minor fraction was precipitated to Ca-bound $\mathrm{P}$.

Data availability: The entire dataset is provided on the SeaNoe database

Ait Ballagh Fatima Ezzahra, Rabouille Christophe, Andrieux-Loyer Françoise, Soetaert Karline, Lansard Bruno, Bombled Bruno, Monvoisin Gaël, Elkalay Khalid, Khalil Karima 
prodelta sediments (NW Mediterranean Sea, France): a data-model approach. SEANOE.

https://doi.org/10.17882/73204

\section{References}

751

752

753

754

755

756

757

758

759

760

761

762

763

764

765

766

767

768

769

770

771

772

773

774

775

776

777

778

779

780

781

Ait Ballagh, F. E., C. Rabouille, F. Andrieux-loyer, K. Soetaert, K. Elkalay, and K. Khalil. 2020. Spatio-temporal dynamics of sedimentary phosphorus along two temperate eutrophic estuaries : A data-modelling approach. Continental Shelf Research 193. Elsevier Ltd: 104037. https://doi.org/10.1016/j.csr.2019.104037.

Andrieux-Loyer, F., and A. Aminot. 2001. Phosphorus forms related to sediment grain size and geochemical characteristics in french coastal areas. Estuarine, Coastal and Shelf Science 52: 617-629. https://doi.org/10.1006/ecss.2001.0766.

Andrieux-Loyer, F., X. Philippon, G. Bally, R. Kérouel, A. Youenou, and J. Le Grand. 2008. Phosphorus dynamics and bioavailability in sediments of the Penzé Estuary (NW France): in relation to annual P-fluxes and occurrences of Alexandrium Minutum. Biogeochemistry 88: 213-231. https://doi.org/10.1007/s10533-008-9199-2.

Anschutz, P., S. Zhong, B. Sundby, A. Mucci, and C. Gobeil. 1998. Burial efficiency of phosphorus and the geochemistry of iron in continental margin sediments. Limnology and Oceanography 43: 53-64. https://doi.org/10.4319/1o.1998.43.1.0053.

Antoine, D., and A. Morel. 1995. Algal pigment distribution and primary production in the eastern Mediterranean as derived from coastal zone color scanner observations. Journal of Physical Oceanography Research 100: 16,193-16,209.

Antonelli, C., F. Eyrolle, B. Rolland, M. Provansal, and F. Sabatier. 2008. Suspended sediment and 137Cs fluxes during the exceptional December 2003 flood in the Rhone River, southeast $\quad$ France. $\quad$ Geomorphology $\quad$ 95: 350-360. https://doi.org/10.1016/j.geomorph.2007.06.007.

Antonelli, C., M. Provansal, and C. Vella. 2004. Recent morphological channel changes in a deltaïc environment. The case of the Rhône River, France. Geomorphology 57: 385-402. https://doi.org/10.1016/S0169-555X(03)00167-3.

Arnau, P., C. Liquete, and M. Canals. 2004. River mouth plume events and their dispersal in the northwestern Mediterranean Sea. Oceanography 17: 23-31.

Balls, P. W. 1994. Nutrient Inputs to Estuaries from Nine Scottish East Coast Rivers; Influence of Estuarine Processes on Inputs to the North Sea. Estuarine, Coastal and Shelf Science. https://doi.org/10.1006/ecss.1994.1068.

Batker, D., I. De la Torre, R. Costanza, J.W. Day, P. Swedeen, R. Boumans, and K.J. Bagstad. 2014. The Threats to the Value of Ecosystem Goods and Services of the Mississippi Delta. 
In Perspectives on the restoration of the Mississippi Delta: The once and future delta, $155-173$.

784

785

786

787

788

789

790

791

792

793

794

795

796

797

798

799

800

801

802

803

804

805

806

807

808

809

810

811

812

813

814

815

816

817

818

Benitez-Nelson, C. R. 2000. The biogeochemical cycling of phosphorus in marine systems. Earth Science Reviews 51: 109-135. https://doi.org/10.1016/S0012-8252(00)00018-0.

Berg, P., S. Rysgaard, and B. Thamdrup. 2003. Dynamic modeling of early diagenesis and nutrient cycling. A case study in an arctic sediment. American Journal of Science 303: 905-955.

Berner, R. A. 1970. Sedimentary pyrite formation. American Journal of Science 268: 1-23.

Berner, R. A. 1980. Early Diagenesis: A Theoretical Approach. In Princeton: Princeton University Press, 241 pp. https://doi.org/10.1016/j.giq.2006.06.002.

Berner, R. A. 1989. Biogeochemical cycles of carbon and sulfur and their effect on atmospheric oxygen over phanerozoic time. Global and Planetary Change 1: 97-122. https://doi.org/10.1016/0921-8181(89)90018-0.

Bianchi, T. S., and M. A. Allison. 2009. Large-river delta-front estuaries as natural "recorders" of global environmental change. Proceedings of the National Academy of Sciences 106: 8085-8092. https://doi.org/10.1073/pnas.0812878106.

Boudreau, B. P. 1997. Diagenetic models and their implementation. Modelling transport and reactions in aquatic sediments. Springer-Verlag. https://doi.org/10.1016/S02648172(98)80005-6.

Boudreau, Bernard P. 1996. A method-of-line code for carbon and nutrient daigenesis in aquatic sediments. Computer \& Geosciences 22: 479-496.

Burdige, D. J. 2007. Preservation of Organic Matter in Marine Sediments: Controls, Mechanisms, and an Imbalance in Sediment Organic Carbon Budgets? Chemical Reviews 107: 467-485. https://doi.org/10.1021/cr050347q.

Cade-Menun, B. J., S. Duhamel, R. J. Dodd, C. Lønborg, C. T. Parsons, and W. D. Taylor. 2019. Editorial: Phosphorus Along the Soil-Freshwater-Ocean Continuum. In Frontiers in Marine Science, 10:1-3. https://doi.org/10.1071/en13151.

Cai, W. J., and F. L. Sayles. 1996. Oxygen penetration depths and fluxes in marine sediments. Marine Chemistry 52: 123-131. https://doi.org/10.1016/0304-4203(95)00081-X.

Canavan, R. W., and C. P. Slomp. 2006. Phosphorus cycling in the sediment of a coastal freshwater lake and response to salinization. In Biogeochemical Cycling of Nutrients and Trace Metals in the Sediment of Haringvliet Lake: Response to Salinization, 95-113.

Canavan, Richard W., Caroline P. Slomp, Parisa Jourabchi, Philippe Van Cappellen, Anniet M. Laverman, and Gerard A. van den Berg. 2006. Organic matter mineralization in sediment of a coastal freshwater lake and response to salinization. Geochimica et Cosmochimica Acta 70: 2836-2855. https://doi.org/10.1016/j.gca.2006.03.012.

Canfield, D. E.., E. Kristensen, and B. Thamdrup. 2005. The Iron and Manganese Cycles. 
Cathalot, C. 2008. Devenir et impact des apports fluviaux sur les marges continentales: importance biogéochimique et environnementale du recyclage dans les sédiments du prodelta du Rhône. Ph.D. thesis, Université Pierre et Marie Curie, Paris, France.

Cathalot, C., C. Rabouille, L. Pastor, B. Deflandre, E. Viollier, R. Buscail, A. Grémare, C. Treignier, and A. Pruski. 2010. Temporal variability of carbon recycling in coastal sediments influenced by rivers : assessing the impact of flood inputs in the Rhone River prodelta. Biogeosciences 7: 1187-1205.

Cathalot, C., C. Rabouille, N. Tisnérat-Laborde, F. Toussaint, P. Kerhervé, R. Buscail, K. Loftis, et al. 2013. The fate of river organic carbon in coastal areas: A study in the RhÔne River delta using multiple isotopic $(\delta 13 \mathrm{C}, \delta 14 \mathrm{C})$ and organic tracers. Geochimica et Cosmochimica Acta 118: 33-55. https://doi.org/10.1016/j.gca.2013.05.001.

Charmasson, S., O. Radakovitch, M. Arnaud, P. Bouisset, and A. S. Pruchon. 1998. Long-core profiles of137Cs, $134 \mathrm{Cs}, 60 \mathrm{Co}$ and $210 \mathrm{~Pb}$ in sediment near the Rhône River (Northwestern Mediterranean Sea). Estuaries 21: 367-378. https://doi.org/10.1007/BF02690450.

Clayton, T. D., and R. H. Byrne. 1993. Spectrophotometric seawater pH measurements : total hydrogen results. Deep-Sea Research 40: 2115-2129. https://doi.org/10.1016/09670637(93)90048-8.

Cloern, J. E. 2001. Our evolving conceptual model of the coastal eutrophication problem. Marine Ecology Progress Series 210: 223-253.

Dedieu, K., C. Rabouille, F. Gilbert, K. Soetaert, E. Metzger, C. Simonucci, D. Jézéquel, et al. 2007. Coupling of carbon, nitrogen and oxygen cycles in sediments from a Mediterranean lagoon: A seasonal perspective. Marine Ecology Progress Series 346: 45-59. https://doi.org/10.3354/meps07031.

Delaney, M L. 1998. Phosphorus accumulation in marine sediments and the oceanic phosphorus cycle. Glob. Biogeochem. Cycles, 12: 563-572.

Diaz, F., P. Raimbault, B. Boudjellal, N. Garcia, and T. Moutin. 2001. Early spring phosphorus limitation of primary productivity in a NW Mediterranean coastal zone ( Gulf of Lions ) 211: 51-62.

Diaz, R. J., and R. Rosenberg. 2008. Spreading dead zones and consequences for marine ecosystems. Science 321: 926-929. https://doi.org/10.1126/science.1156401.

Dickson, A G, C. L. Sabine, and J. R. Christian. 2007. Guide to Best Practices for Ocean CO2 Measurements. In PICES Special Publication, 3:191 pp.

Dijkstra, N., C. P. Slomp, and T. Behrends. 2016. Vivianite is a key sink for phosphorus in sediments of the Landsort Deep, an intermittently anoxic deep basin in the Baltic Sea. $\begin{array}{lllll}\text { Chemical Geology } & \text { 438. } & \text { Elsevier } & \text { B.V.: } & 58-72 .\end{array}$ https://doi.org/10.1016/j.chemgeo.2016.05.025. 
Downing, J. A., M. McClain, R. Twilley, J. M. Melack, J. Elser, N. N. Rabalais, W. M. Lewis, et al. 1999. The impact of accelerating land-use change on the N-cycle of tropical aquatic ecosystems: Current conditions and projected changes. Biogeochemistry 46: 109-148. https://doi.org/10.1007/BF01007576.

Dugdale, R. C., and F. P. Wilkerson. 1988. Nutrient sources and primary production in the Eastern Mediterranean. Oceanologica Acta: 179-184.

Dumoulin, J. P., L. Pozzato, J. Rassman, F. Toussaint, M. Fontugne, N. Tisnérat-Laborde, L. Beck, et al. 2018. Isotopic signature $(\delta 13 \mathrm{C}, \delta 14 \mathrm{C})$ of DIC in sediment pore waters: An example from the rhone river delta. Radiocarbon 60: 1465-1481. https://doi.org/10.1017/RDC.2018.111.

Egger, M., T. Jilbert, T. Behrends, C. Rivard, and C. P. Slomp. 2015. Vivianite is a major sink for phosphorus in methanogenic coastal surface sediments. Geochimica et Cosmochimica Acta 169. Elsevier Ltd: 217-235. https://doi.org/10.1016/j.gca.2015.09.012.

Emerson, S., J. Hedges, H. D. Holland, and K. K. Turekian. 2004. Sediment diagenesis and benthic flux. The Oceans and Marine Geochemistry 6: 293-319.

Emerson, S., and G. Widmer. 1978. Early diagenesis in anaerobic lake sediments-II. Thermodynamic and kinetic factors controlling the formation of iron phosphate. Geochimica et Cosmochimica Acta 42: 1307-1316. https://doi.org/10.1016/00167037(78)90035-2.

Emsley, J. 1980. The Phosphorus Cycle. In The handbook of environmental chemistry, 20:147167. https://doi.org/10.1016/0143-1471(82)90111-8.

Estournel, C., V. Kondrachoff, P. Marsaleix, and R. Vehil. 1997. The plume of the Rhone: Numerical simulation and remote sensing. Continental Shelf Research 17: 899-924. https://doi.org/10.1016/S0278-4343(96)00064-7.

Eyrolle, F., O. Radakovitch, P. Raimbault, S. Charmasson, C. Antonelli, E. Ferrand, D. Aubert, G. Raccasi, S. Jacquet, and R. Gurriaran. 2012. Consequences of hydrological events on the delivery of suspended sediment and associated radionuclides from the Rhône River to the Mediterranean Sea. Journal of Soils and Sediments 12: 1479-1495. https://doi.org/10.1007/s11368-012-0575-0.

Ferrón, S, T Ortega, and J M Forja. 2009. Benthic respiration on the northeastern shelf of the Gulf of Cádiz ( SW Iberian Peninsula ). Marine Ecology Progress Series 392: 69-80. https://doi.org/10.3354/meps08240.

Filippelli, G. M., and M. L. Delaney. 1996. Phosphorus geochemistry of equatorial Pacific sediments. Geochimica et Cosmochimica Acta 60: 1479-1495. https://doi.org/10.1016/0016-7037(96)00042-7.

Fox, L. E. 1990. Geochemistry of dissolved phosphate in the Sepik River and Estuary, Papua, New Guinea. Geochimica et Cosmochimica Acta 54: 1019-1024. https://doi.org/10.1016/0016-7037(90)90435-N. 
Froelich, P. N. 1988. Kinetic control of dissolved phosphate in natural rivers and estuaries: A primer on the phosphate buffer mechanism. Limnology and Oceanography 33: 649-668.

Gatti, J., A. Petrenko, J. L. Devenon, Y. Leredde, and C. Ulses. 2006. The Rhone river dilution zone present in the northeastern shelf of the Gulf of Lion in December 2003. Continental Shelf Research 26: 1794-1805. https://doi.org/10.1016/j.csr.2006.05.012.

Got, H., and J. C. Aloisi. 1990. The Holocene sedimentation on the Gulf of Lions margin: a quantitative approach. Continental Shelf Research 10: 841-855. https://doi.org/10.1016/0278-4343(90)90062-Q.

Grasshof, K., M. Ehrhardt, and K. Kremling. 1983. Methods of seawater analysis, Third, Completely Revised and Extended Edition. Verlag Chemie GmbH. https://doi.org/10.1016/0304-4203(78)90045-2.

Gypens, Nathalie, Christiane Lancelot, and Karline Soetaert. 2008. Simple parameterisations for describing N and P diagenetic processes: Application in the North Sea. Progress in Oceanography 76: 89-110. https://doi.org/10.1016/j.pocean.2007.10.003.

Hammond, D E. 1999. Diagenesis of carbon and nutrients and benthic exchange in sediments of the Northern Adriatic Sea. Marine Chemistry 66: 53-79.

Hansen, H. P., and F. Koroleff. 1999. Determination of nutrients. In Methods of Seawater Analysis, Third Edition, Completely Revised and Extended Edition, 159-228. https://doi.org/10.1002/9783527613984.

Hofmann, A. F., K. Soetaert, and J. J. Middelburg. 2008. Present nitrogen and carbon dynamics in the Scheldt estuary using a novel 1-D model. Biogeosciences 5: 981-1006. https://doi.org/10.5194/bg-5-981-2008.

Howarth, RW, G Billen, D Swaney, A Townsend, N Jaworski, K Lajtha, JA Downing, et al. 1996. Regional nitrogen budgets and riverine N \& P fluxes for the drainages to the North Atlantic Ocean: Natural and human influences. Biogeochemistry 35: 75-139. https://doi.org/10.1590/2318-0331.011616030.

Ibañez, C., D. Pont, and N. Prat. 1997. Characterization of the Ebre and Rhone estuaries: A basis for defining and classifying salt-wedge estuaries. Limnology and Oceanography 42: 89-101. https://doi.org/10.4319/1o.1997.42.1.0089.

Jackson, J. B.C., M. X. Kirby, W. H. Berger, K. A. Bjorndal, L. W. Botsford, B. J. Bourque, R. H. Bradbury, et al. 2001. Historical overfishing and the recent collapse of coastal ecosystems. Science 293: 629-637. https://doi.org/10.1126/science.1059199.

Joshi, S. R., R. K. Kukkadapu, D. J. Burdige, M. E. Bowden, D. L. Sparks, and D. P. Jaisi. 2015. Organic matter remineralization predominates phosphorus cycling in the mid-bay sediments in the chesapeake bay. Environmental Science and Technology 49: 5887-5896. https://doi.org/10.1021/es5059617.

Khalil, K, A M Laverman, M Raimonet, and C Rabouille. 2018. Importance of nitrate reduction in benthic carbon mineralization in two eutrophic estuaries : Modeling, observations and 
laboratory experiments. Marine Chemistry 199. Elsevier: 24-36. https://doi.org/10.1016/j.marchem.2018.01.004.

Kraal, P., E. D. Burton, A. L. Rose, B. D. Kocar, R. S. Lockhart, K. Grice, R. T. Bush, E. Tan, and S. M. Webb. 2015. Sedimentary iron-phosphorus cycling under contrasting redox conditions in a eutrophic estuary. Chemical Geology 392. Elsevier B.V.: 19-31. https://doi.org/10.1016/j.chemgeo.2014.11.006.

Krom, M. D., and R. A. Berner. 1981. The diagenesis of phosphorus in a nearshore marine sediment. Geochimica et Cosmochimica Acta 45: 207-216. https://doi.org/10.1016/00167037(81)90164-2.

Krom, M. D., N. Kress, S. Brenner, and L. I. Gordon. 1991. Phosphorus limitation of primary productivity in the eastern Mediterranean Sea. Limnology and Oceanography 36: 424432. https://doi.org/10.4319/1o.1991.36.3.0424.

Lansard, B., S. Charmasson, C. Gascó, M. P. Antón, C. Grenz, and M. Arnaud. 2007. Spatial and temporal variations of plutonium isotopes $(238 \mathrm{Pu}$ and $239,240 \mathrm{Pu})$ in sediments off the Rhone River mouth (NW Mediterranean). Science of the Total Environment 376: 215227. https://doi.org/10.1016/j.scitotenv.2007.01.069.

Lansard, B., C. Rabouille, L. Denis, and C. Grenz. 2008. In situ oxygen uptake rates by coastal sediments under the influence of the Rhône River (NW Mediterranean Sea). Continental Shelf Research 28: 1501-1510. https://doi.org/10.1016/j.csr.2007.10.010.

Lansard, B., C. Rabouille, L. Denis, and C. Grenz. 2009. Benthic remineralization at the landocean interface: A case study of the Rhône River (NW Mediterranean Sea). Estuarine, Coastal and Shelf Science 81. Elsevier Ltd: 544-554. https://doi.org/10.1016/j.ecss.2008.11.025.

Lebo, M. E. 1991. Particle-bound phosphorus along an urbanized coastal plain estuary. Marine Chemistry 34: 225-246. https://doi.org/10.1016/0304-4203(91)90005-H.

Lehtoranta, J., O. P. Savchuk, J. Elken, K. Dahlbo, H. Kuosa, M. Raateoja, P. Kauppila, A. Räike, and H. Pitkänen. 2017. Atmospheric forcing controlling inter-annual nutrient dynamics in the open Gulf of Finland. Journal of Marine Systems 171. Elsevier B.V: 420. https://doi.org/10.1016/j.jmarsys.2017.02.001.

Lenstra, W. K., M. Egger, N. A. G. M. van Helmond, E. Kritzberg, D. J. Conley, and C. P. Slomp. 2018. Variations in river input of iron impact sedimentary phosphorus burial in an oligotrophic Baltic Sea estuary. Biogeosciences Discussions 15: 6979-6996. https://doi.org/10.1021/pr100554m.

Lochet, F., and M. Leveau. 1990. Transfers between a eutrophic ecosystem, the river Rh8ne, and an oligotrophic ecosystem, the north-western Mediterranean Sea. Hydrobiologia 207: 95-103.

Ludwig, W., E. Dumont, M. Meybeck, and S. Heussner. 2009. River discharges of water and nutrients to the Mediterranean and Black Sea: Major drivers for ecosystem changes during 
past and future decades? Progress in Oceanography 80. Elsevier Ltd: 199-217. https://doi.org/10.1016/j.pocean.2009.02.001.

Ludwig, W., and J. L. Probst. 1998. River sediment discharge to the oceans: Present-day controls and global budgets. American Journal of Science 298: 265-295. https://doi.org/10.2475/ajs.298.4.265.

Malagó, A., F. Bouraoui, B. Grizzetti, and A. De Roo. 2019. Modelling nutrient fluxes into the Mediterranean Sea. Journal of Hydrology: Regional Studies 22. Elsevier: 100592. https://doi.org/10.1016/j.ejrh.2019.01.004.

McKee, B. A., R. C. Aller, M. A. Allison, T. S. Bianchi, and G. C. Kineke. 2004. Transport and transformation of dissolved and particulate materials on continental margins influenced by major rivers: Benthic boundary layer and seabed processes. Continental Shelf Research 24: 899-926. https://doi.org/10.1016/j.csr.2004.02.009.

Meybeck, M. 1982. Carbon, nitrogen, and phosphorus transport by world rivers. American Journal of Science 282: 401-450.

Milliman, J. D., and R. H. Meade. 1983. World-Wide Delivery of River Sediment to the Oceans. The Journal of Geology 91: 1-21.

Miralles, J., O. Radakovitch, and J. C. Aloisi. 2005. 210Pb sedimentation rates from the Northwestern Mediterranean margin. Marine Geology 216: 155-167. https://doi.org/10.1016/j.margeo.2005.02.020.

Morse, J. W., and P. M. Eldridge. 2007. A non-steady state diagenetic model for changes in sediment biogeochemistry in response to seasonally hypoxic/anoxic conditions in the "dead zone" of the Louisiana shelf. Marine Chemistry 106: 239-255. https://doi.org/10.1016/j.marchem.2006.02.003.

Moutin, T., P. Raimbault, H.L Golterman, and B. Coste. 1998. The input of nutrients by the Rhône river into the Mediterranean Sea: recent observations and comparison with earlier data. Hydrobiologia 373/374: 237-246. https://doi.org/10.1023/A.

Moutin, T, and P Raimbault. 2002. Primary production, carbon export and nutrients availability in western and eastern Mediterranean Sea in early summer 1996 ( MINOS cruise ). Journal of Marine Systems 33-34: 273-288.

Moutin, T, F Van Wambeke, and L Prieur. 2012. Introduction to the Biogeochemistry from the Oligotrophic to the Ultraoligotrophic Mediterranean (BOUM) experiment. Biogeosciences 9: 3817-3825. https://doi.org/10.5194/bg-9-3817-2012.

Muller-Karger, F. E., R. Varela, R. Thunell, R. Luerssen, C. Hu, and J. J. Walsh. 2005. The importance of continental margins in the global carbon cycle. Geophysical Research Letters 32: 1-4. https://doi.org/10.1029/2004GL021346.

Murphy, J., and J. P. Riley. 1962. A modified single solution method for determination of phosphate in natural waters. Analytica Chimica Acta 27: 31-36. https://doi.org/10.1057/9781137461131. 
Naudin, J. J., G. Cauwet, M. J. Chrétiennot-Dinet, B. Deniaux, J. L. Devenon, and H. Pauc. 1997. River discharge and wind influence upon particulate transfer at the land-ocean interaction: Case study of the Rhone River plume. Estuarine, Coastal and Shelf Science 45: 303-316. https://doi.org/10.1006/ecss.1996.0190.

Nixon, S. W. 1995. Coastal marine eutrophication: A definition, social causes, and future concerns. Ophelia 41: 199-219. https://doi.org/10.1080/00785236.1995.10422044.

Ollivier, P., B. Hamelin, and O. Radakovitch. 2010. Seasonal variations of physical and chemical erosion: A three-year survey of the Rhone River (France). Geochimica et Cosmochimica Acta 74. Elsevier Ltd: 907-927. https://doi.org/10.1016/j.gca.2009.10.037.

Pastor, L., C. Cathalot, B. Deflandre, E. Viollier, K. Soetaert, F. J.R. Meysman, C. Ulses, E. Metzger, and C. Rabouille. 2011. Modeling biogeochemical processes in sediments from the Rhǒne River prodelta area (NW Mediterranean Sea). Biogeosciences 8: 1351-1366. https://doi.org/10.5194/bg-8-1351-2011.

Pont, D., J. P. Simonnet, and A. V. Walter. 2002. Medium-term changes in suspended sediment delivery to the ocean: Consequences of catchment heterogeneity and river management (Rhône River, France). Estuarine, Coastal and Shelf Science 54: 1-18. https://doi.org/10.1006/ecss.2001.0829.

Powley, H. R., M. D. Krom, and P. Van Cappellen. 2017. Understanding the unique biogeochemistry of the Mediterranean Sea: Insights from a coupled phosphorus and nitrogen model. Global Biogeochemical Cycles 31: 1010-1031. https://doi.org/10.1002/2017GB005648.

Pozzato, L., J. Rassmann, B. Lansard, J-P. Dumoulin, P. van Breugel, C. Rabouille. 2018. Origin of remineralized organic matter in sediments from the Rhone River prodelta (NW Mediterranean) traced by G14C and g13C signatures of pore water DIC. Progr. Oceanogr., 163: 112-122.

Provansal, M., O. Radakovitch, F. Sabatier, and A. Clémens. 2012. Le Rhône aval en 21 questions. Rapport ZABR, Graie Editors, Villeurbanne, France

Psenner, R., B. Bostrom, M. Dinka, K. Pettersson, R. Pucsko, and M. Sager. 1988. Fractionation of phosphorus in suspended matter and sediment. Ergebnisse der Limnologie 22: 219-228.

Rabouille, C., D. J. Conley, M. H. Dai, W. J. Cai, C. T.A. Chen, B. Lansard, R. Green, et al. 2008. Comparison of hypoxia among four river-dominated ocean margins: The Changjiang (Yangtze), Mississippi, Pearl, and Rhône rivers. Continental Shelf Research 28: 1527-1537. https://doi.org/10.1016/j.csr.2008.01.020.

Rabouille, C., L. Denis, K. Dedieu, G. Stora, B. Lansard, and C. Grenz. 2003. Oxygen demand in coastal marine sediments: Comparing in situ microelectrodes and laboratory core incubations. Journal of Experimental Marine Biology and Ecology 285-286: 49-69. https://doi.org/10.1016/S0022-0981(02)00519-1.

Rabouille, C., and J. F. Gaillard. 1991. Towards the EDGE: Early diagenetic global explanation. 

A model depicting the early diagenesis of organic matter, O2, NO3, Mn, and PO4. Geochimica et Cosmochimica Acta 55: 2511-2525. https://doi.org/10.1016/00167037(91)90369-G.

Radakovitch, O, S Charmasson, M Arnaud, and P Bouisset. 1999. 210Pb and Caesium Accumulation in the Rhône Delta. Estuarine, Coastal and Shelf Science 48: 77-92.

Rassmann, J., E. M. Eitel, C. Cathalot, C. Brandily, B. Lansard, M. Taillefert, and C. Rabouille. 2020. Benthic alkalinity and DIC fluxes in the Rhône River prodelta generated by decoupled aerobic and anaerobic processes. Biogeosciences Discussions.

Rassmann, J., B. Lansard, L. Pozzato, and C. Rabouille. 2016. Carbonate chemistry in sediment porewaters of the Rhône River delta driven by early diagenesis (northwestern Mediterranean). Biogeosciences 13: 5379-5394. https://doi.org/10.5194/bg-13-53792016.

Ratmaya, W. 2018. Rôle des sédiments dans le cycle des nutriments et impacts sur l'eutrophisation des écosystèmes côtiers. Ph.D. thesis, Univ. Bretagne Occidentale, Brest, France.

Revsbech, N. P. 1989. An oxygen microsensor with a guard cathode. Limnology and Oceanography 34: 474-478. https://doi.org/10.4319/lo.1989.34.2.0474.

Ruttenberg, K.C. 1992. Development of a sequential extraction method for different forms of phosphorus in marine sediments. Limnology and Oceanography 37: 1460-1482. https://doi.org/10.4319/1o.1992.37.7.1460.

Ruttenberg, K.C. 2014. 10.13 - The Global Phosphorus Cycle. Treatise on Geochemistry: 499558. https://doi.org/10.1016/B978-0-08-095975-7.00813-5.

Ruttenberg, K.C., and R. A. Berner. 1993. Authigenic apatite formation and burial in sediments from non-upwelling, continental margin environments. Geochimica et Cosmochimica Acta 57: 991-1007. https://doi.org/10.1016/0016-7037(93)90035-U.

Sabatier, F., G. Maillet, M. Provansal, T. J. Fleury, S. Suanez, and C. Vella. 2006. Sediment budget of the Rhône delta shoreface since the middle of the 19th century. Marine Geology 234: 143-157. https://doi.org/10.1016/j.margeo.2006.09.022.

Schnetger, B., and C. Lehners. 2014. Determination of nitrate plus nitrite in small volume marine water samples using vanadium(III)chloride as a reduction agent. Marine Chemistry 160. Elsevier B.V.: 91-98. https://doi.org/10.1016/j.marchem.2014.01.010.

Seeberg-Elverfeldt, J., M. Schlüter, T. Feseker, and M. Kölling. 2005. Rhizon sampling of porewaters near the sediment-water interface of aquatic systems. Limnology and Oceanography: Methods 3: 361-371. https://doi.org/10.4319/1om.2005.3.361.

Slomp, C. P., E. H. G. Epping, W. Helder, and W. V. Raaphorst. 1996. A key role for ironbound phosphorus in authigenic apatite formation in North Atlantic continental platform sediments. Journal of Marine Research 54: 1179-1205. https://doi.org/10.1357/0022240963213745. 
1084

1085

1086

1087

1088

1089

1090

1091

1092

1093

1094

1095

1096

1097

1098

1099

1100

1101

1102

1103

1104

1105

1106

1107

1108

1109

1110

1111

1112

1113

1114

1115

1116

1117

1118

1119

1120

Slomp, C. P., J. F. P. Malschaert, and W. V. Raaphorst. 1998. The role of adsorption in sediment-water exchange of phosphate in North Sea continental margin sediments. Limnology and Oceanography 43: 832-846.

Slomp, C. P., J. Thomson, and G. J. De Lange. 2004. Controls on phosphorus regeneration and burial during formation of eastern Mediterranean sapropels. Marine Geology 203: 141159. https://doi.org/10.1016/S0025-3227(03)00335-9.

Smith, V H, G D Tilman, and J C Nekola. 1999. Eutrophication : impacts of excess nutrient inputs on freshwater, marine, and terrestrial ecosystems. Environmental Pollution 100: 179-196.

Soetaert, K., P. M. J. Herman, and J. J. Middelburg. 1996. A model of early diagenetic processes from the shelf to abyssal depths. Geochimica et Cosmochimica Acta 60: 1019-1040. https://doi.org/10.1016/0016-7037(96)00013-0.

Soetaert, K., and F. Meysman. 2012. Reactive transport in aquatic ecosystems: Rapid model prototyping in the open source software R. Environmental Modelling and Software 32. Elsevier Ltd: 49-60. https://doi.org/10.1016/j.envsoft.2011.08.011.

Stookey, L. L. 1970. Ferrozine-A New Spectrophotometric Reagent for Iron. Analytical Chemistry 42: 779-781.

Sundby, B., C. Gobeil, N. Silverberg, and A Mucci. 1992. The phosphorus cycle in coastal marine sediments. Limnology and Oceanography 37: 1129-1145. https://doi.org/10.4319/1o.1992.37.6.1129.

Syers, J. K., R. F. Harris, and D. E. Armstrong. 1973. Phosphate Chemistry in Lake Sediments. Journal of Environment Quality 2: https://doi.org/10.2134/jeq1973.00472425000200010001x.

Syvitski, J. P. M., A. J. Kettner, I. Overeem, E. W. H. Hutton, M. T. Hannon, G. R. Brakenridge, J. W. Day, et al. 2009. Sinking Deltas. Nature Geoscience 2: 681-686.

Thamdrup, B., H. Fossing and B.B. Jorgensen.1994. Manganese, iron, and sulfur cycling in a coastal marine sediment, Aarhus Bay, Denmark. Geochimica et Cosmochimica Acta, 58, 5115-5129,

Tromp, T.K., P. Van Cappellen, and R.M. Key. 1995. A global model for the early diagenesis of organic carbon and organic phosphorus in marine sediments. Geochimica et Cosmochimica Acta 59: 1259-1284. https://doi.org/10.1016/0016-7037(95)00042-X.

Tyrrell, T. 1999. The relative influences of nitrogen and phosphorus on oceanic primary production. Nature 400: 525-531.

Van Den Broeck, N., and T. Moutin. 2002. Phosphate in the sediments of the Gulf of Lions (NW Mediterranean Sea), relationship with input by the river Rhone. Hydrobiologia 472: 85-94. https://doi.org/10.1023/A:1016308931115.

Vitousek, P. M., H. A. Mooney, J. Lubchenco, and J. M. Melillo. 1997. Human Domination of 
Earth's Ecosystems. Science 277: 494-499. https://doi.org/10.1126/science.277.5325.494.

1122 Wang, Y.F., and P. Van Cappellen. 1996. A multicomponent reactive transport model of early diagenesis: Application to redox cycling in coastal marine sediments. Geochimica et Cosmochimica Acta 60: 2993-3014. https://doi.org/10.1016/0016-7037(96)00140-8.

1125 Wijsman, J. W.M., P. M.J. Herman, J. J. Middelburg, and K. Soetaert. 2002. A model for early diagenetic processes in sediments of the continental shelf of the Black Sea. Estuarine, Coastal and Shelf Science 54: 403-421. https://doi.org/10.1006/ecss.2000.0655.

Wilkinson, G. M. 2017. Eutrophication of Freshwater and Coastal Ecosystems. Encyclopedia of Sustainable Technologies. Vol. 4. Elsevier. https://doi.org/10.1016/B978-0-12-4095489.10160-5. 


\section{Figures}

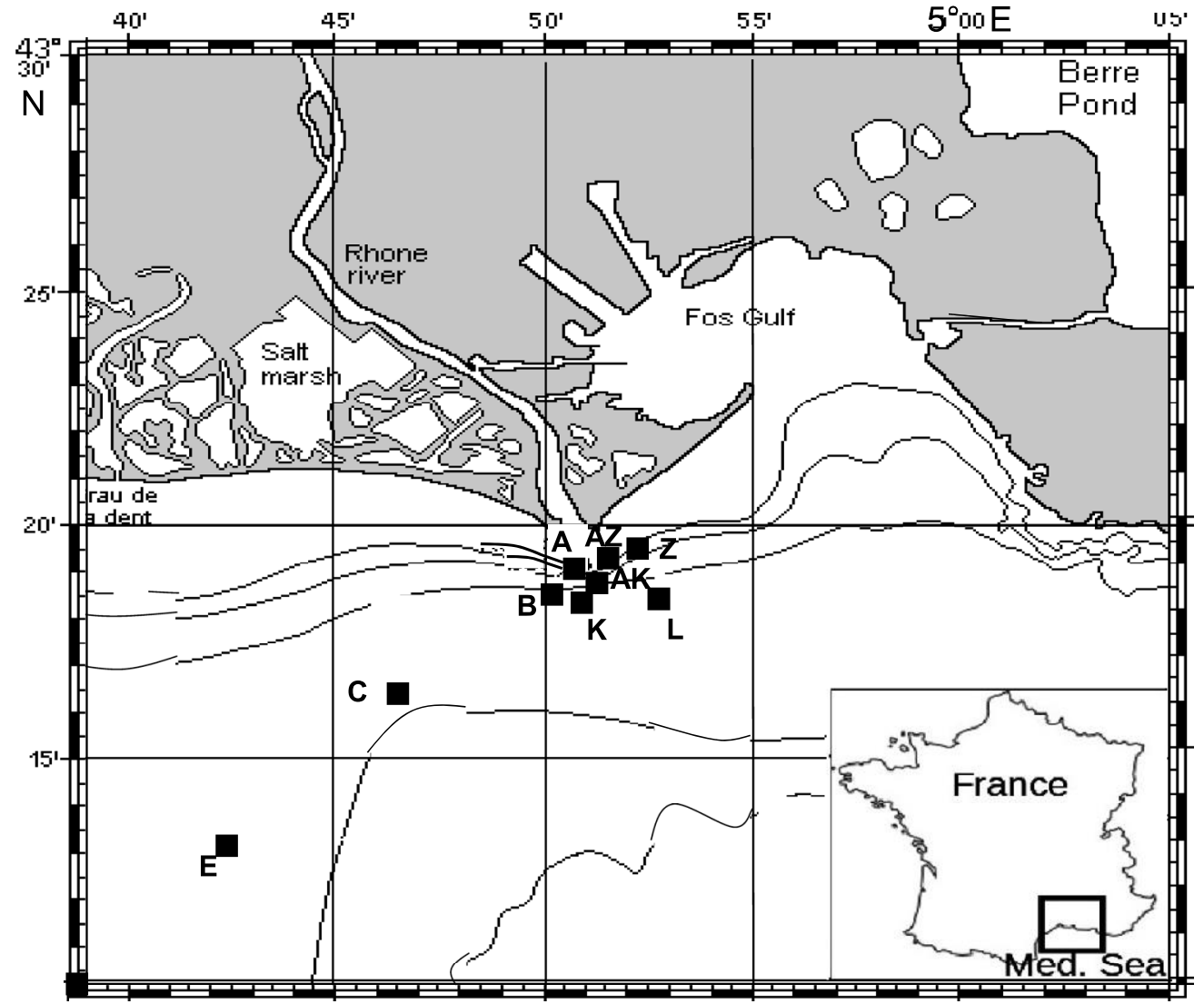

Fig. 1 Location of sampled stations in proximal (stations A, Z, AZ), prodelta (stations $\mathrm{AK}, \mathrm{K}, \mathrm{B}, \mathrm{L})$ and distal $(\mathrm{C}, \mathrm{E})$ domains of the Rhône River delta 


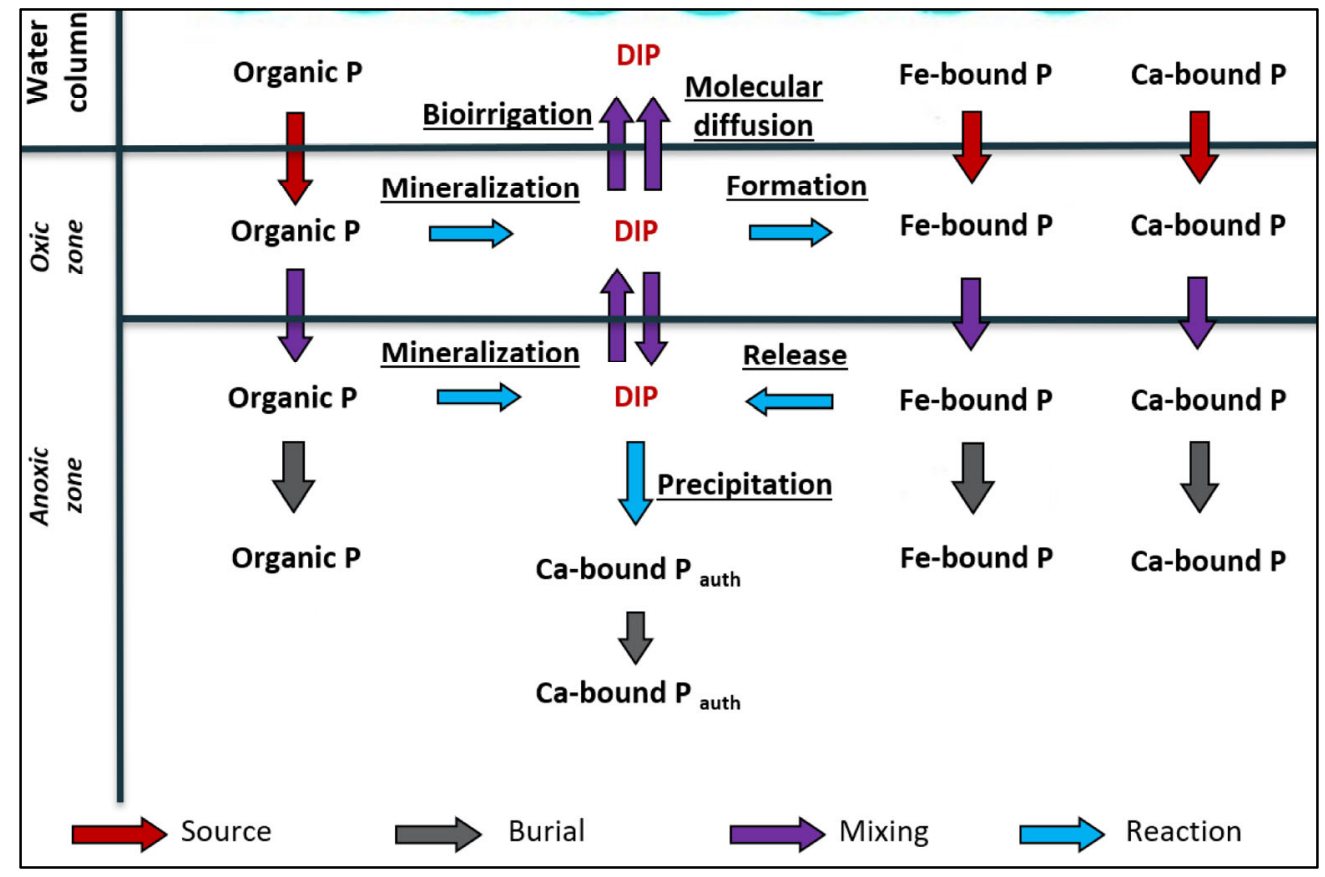

Fig. 2 Schematic representation of benthic $P$ cycle 

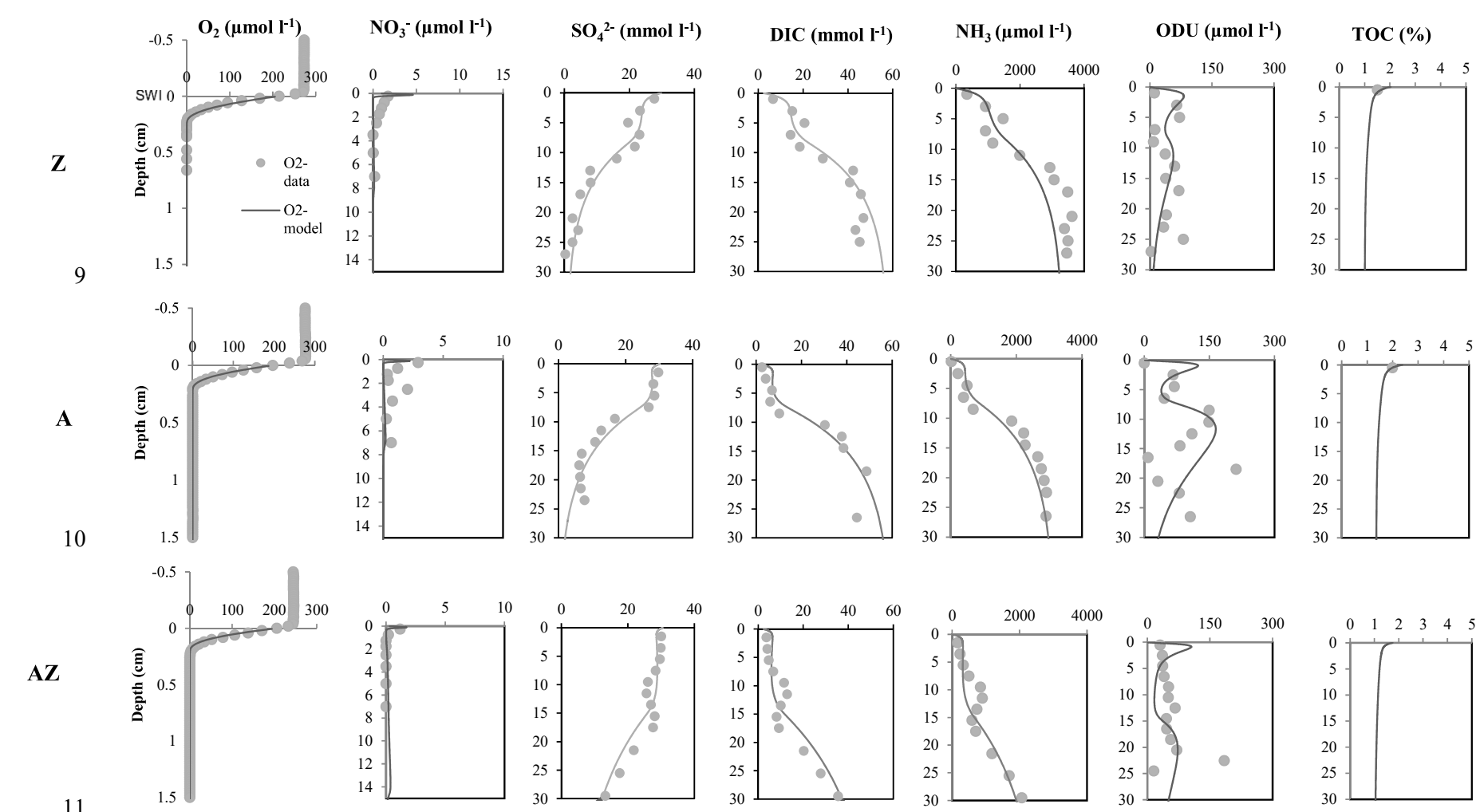

Fig. 3-a Simulated (grey lines) and measured (symbols (॰)) $\mathrm{O}_{2}, \mathrm{NO}_{3}{ }^{-}, \mathrm{SO}_{4}{ }^{2-}, \mathrm{DIC}, \mathrm{NH}_{4}{ }^{+}$, ODU and TOC in the proximal domain (st $\mathrm{Z}, \mathrm{A}$ and $\mathrm{AZ}$ ) 


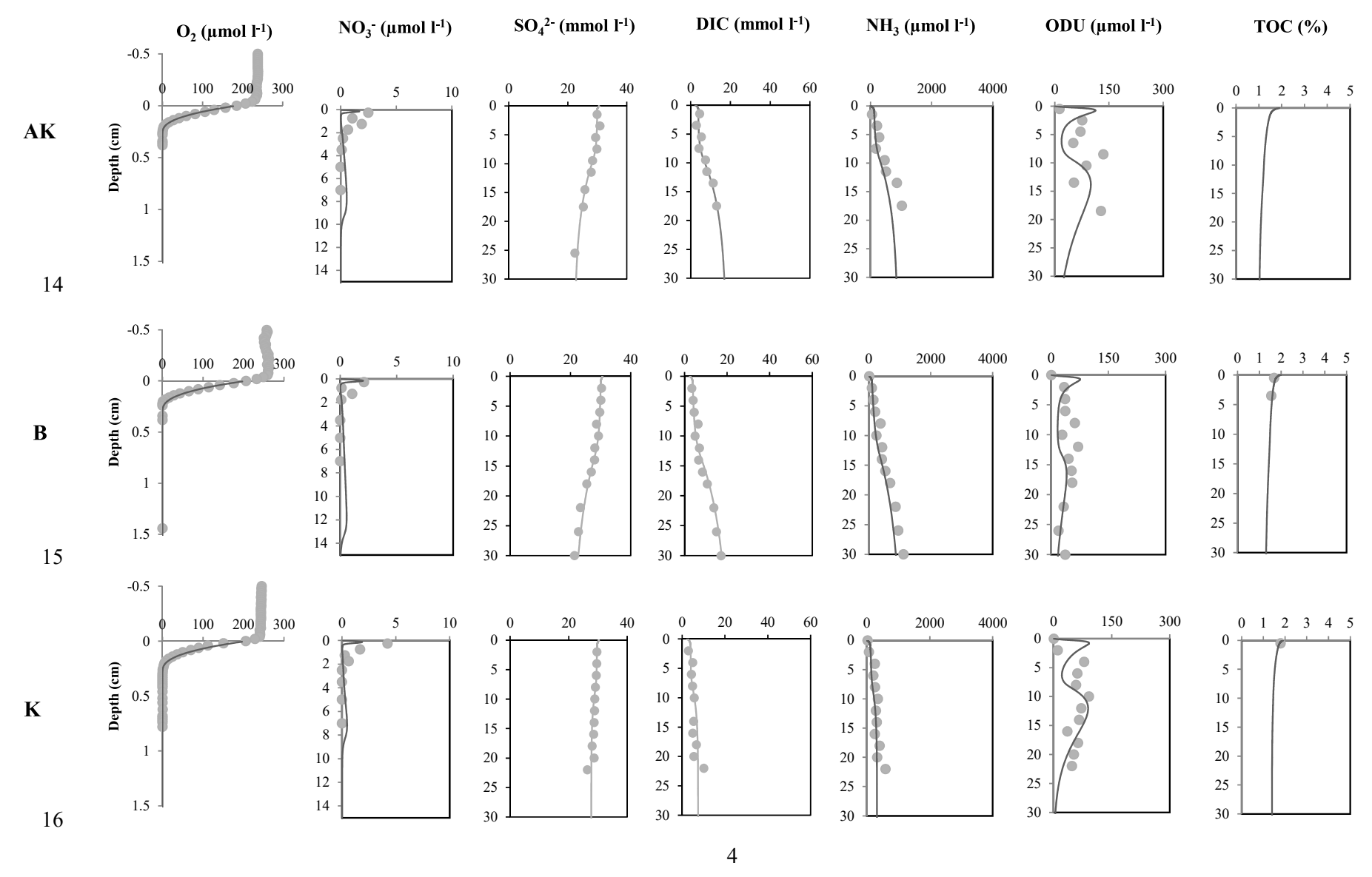



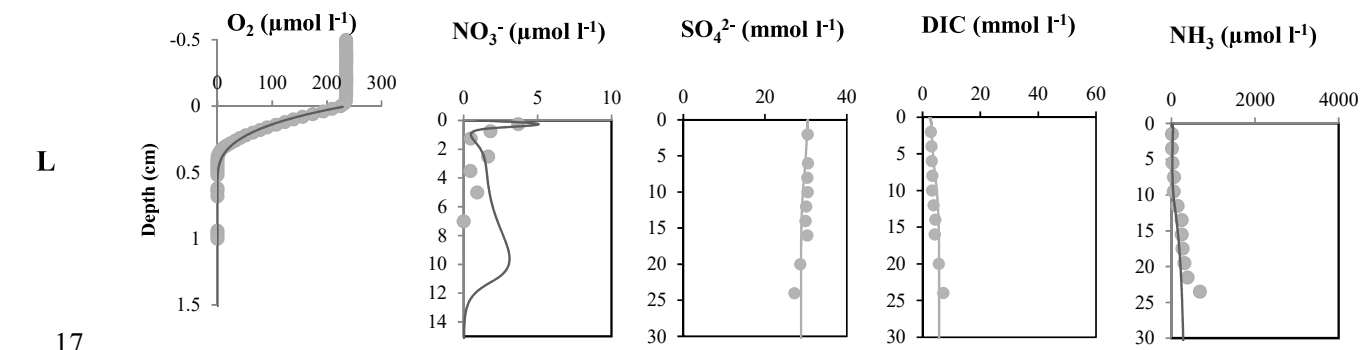

ODU $\left(\mu \mathrm{mol} \mathrm{l^{-1 }}\right)$

TOC (\%)

17

Fig. 3-b. Simulated (grey lines) and measured (symbols (•)) $\mathrm{O}_{2}, \mathrm{NO}_{3}{ }^{-}, \mathrm{SO}_{4}{ }^{2-}, \mathrm{DIC}, \mathrm{NH}_{4}{ }^{+}$, ODU and TOC in the prodelta domain (st $\mathrm{AK}, \mathrm{B}, \mathrm{K}$ and $\mathrm{L}$ ) $-0.5$

C
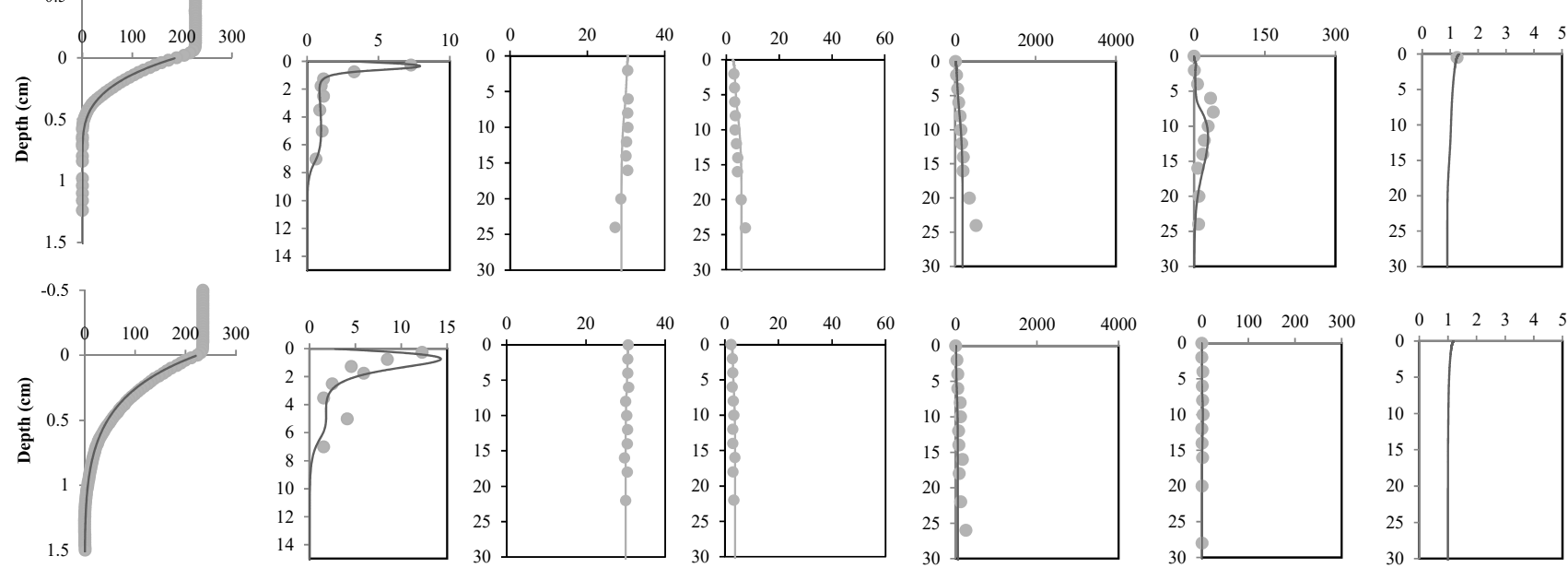

Fig. 3-c. Simulated (grey lines) and measured (symbols (•)) $\mathrm{O}_{2}, \mathrm{NO}_{3}^{-}, \mathrm{SO}_{4}^{2-}, \mathrm{DIC} \mathrm{NH}_{4}{ }^{+}$, ODU and TOC in the distal domain (st C and E) 


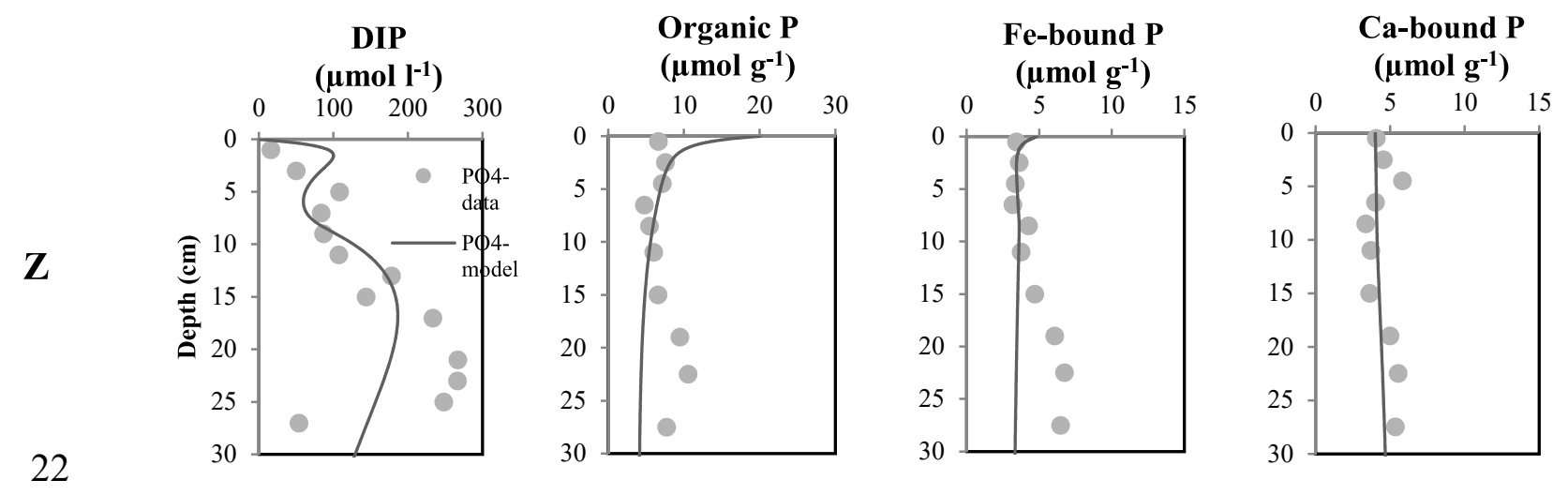

A
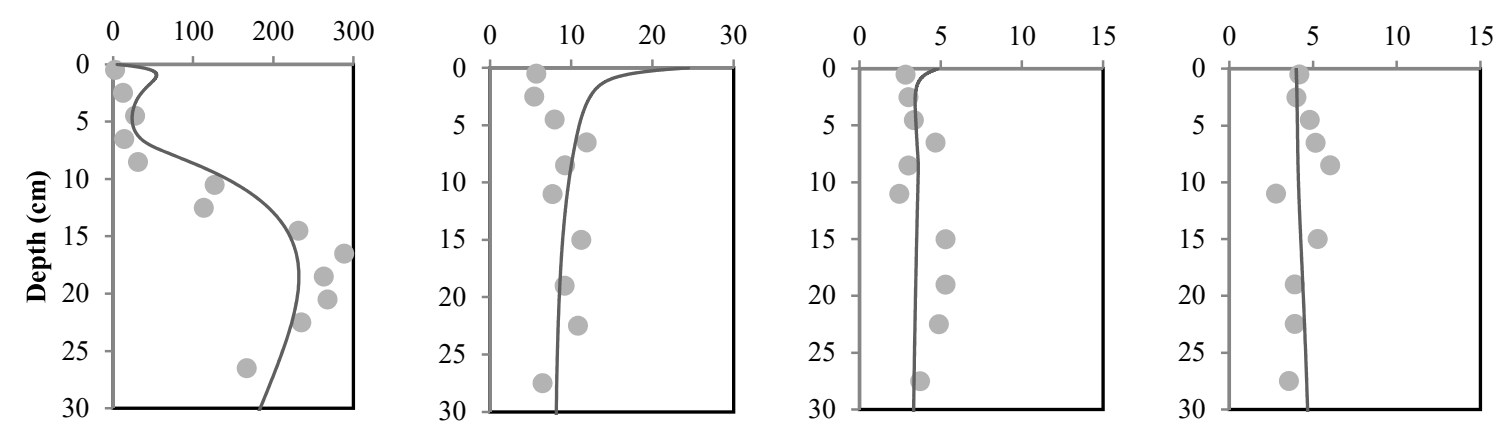

AZ
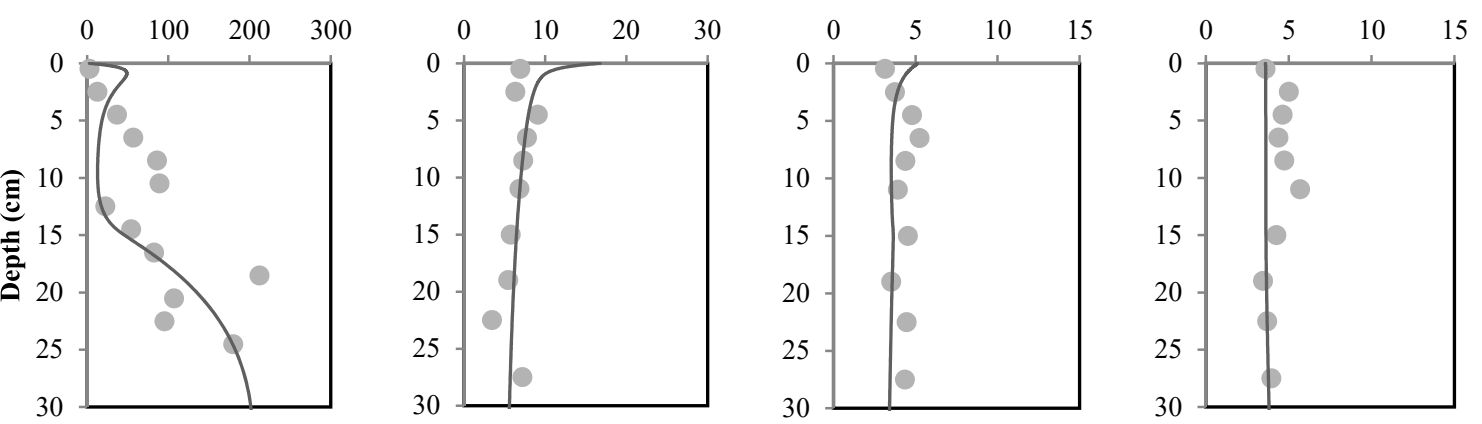

AK
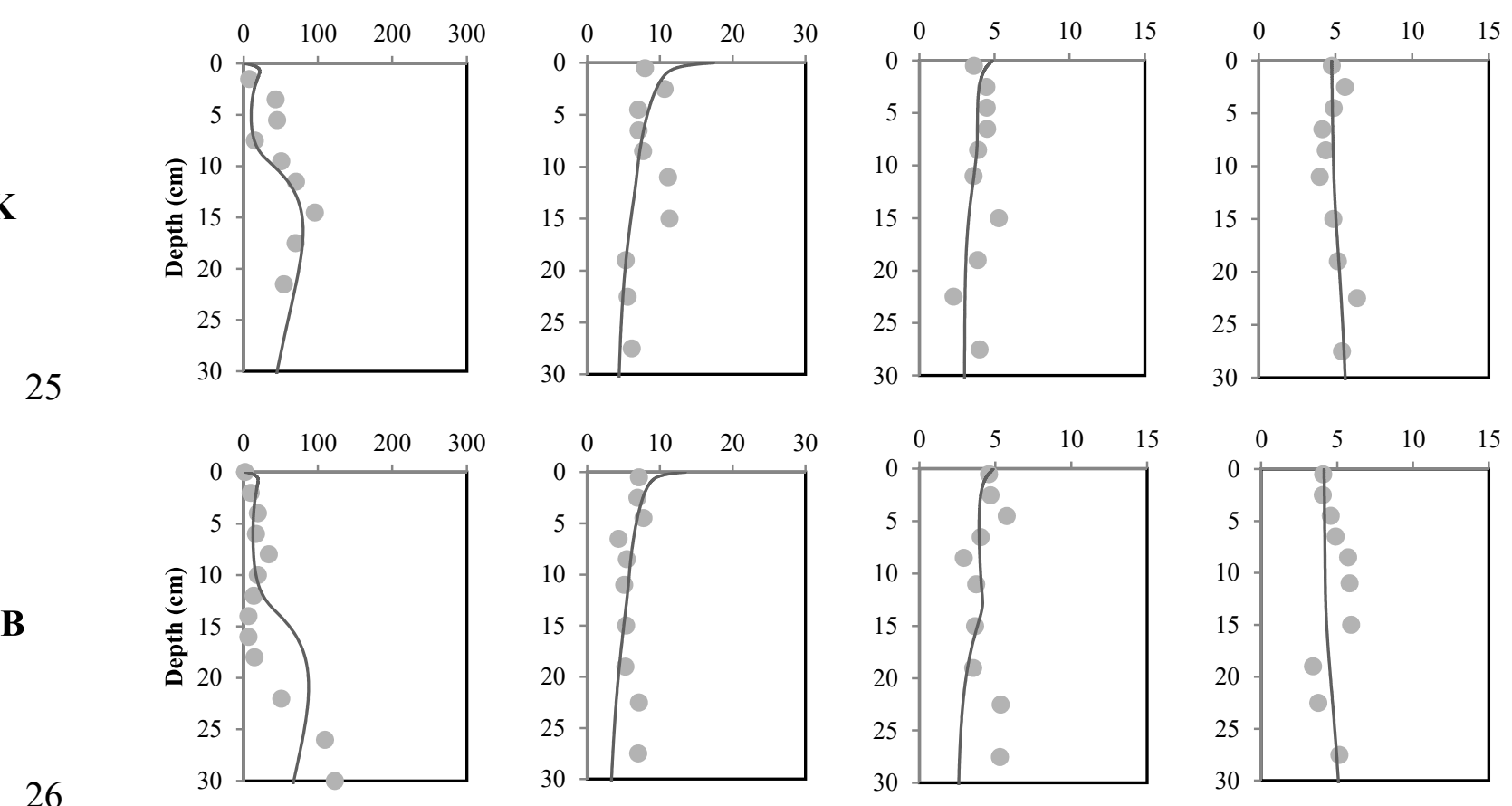

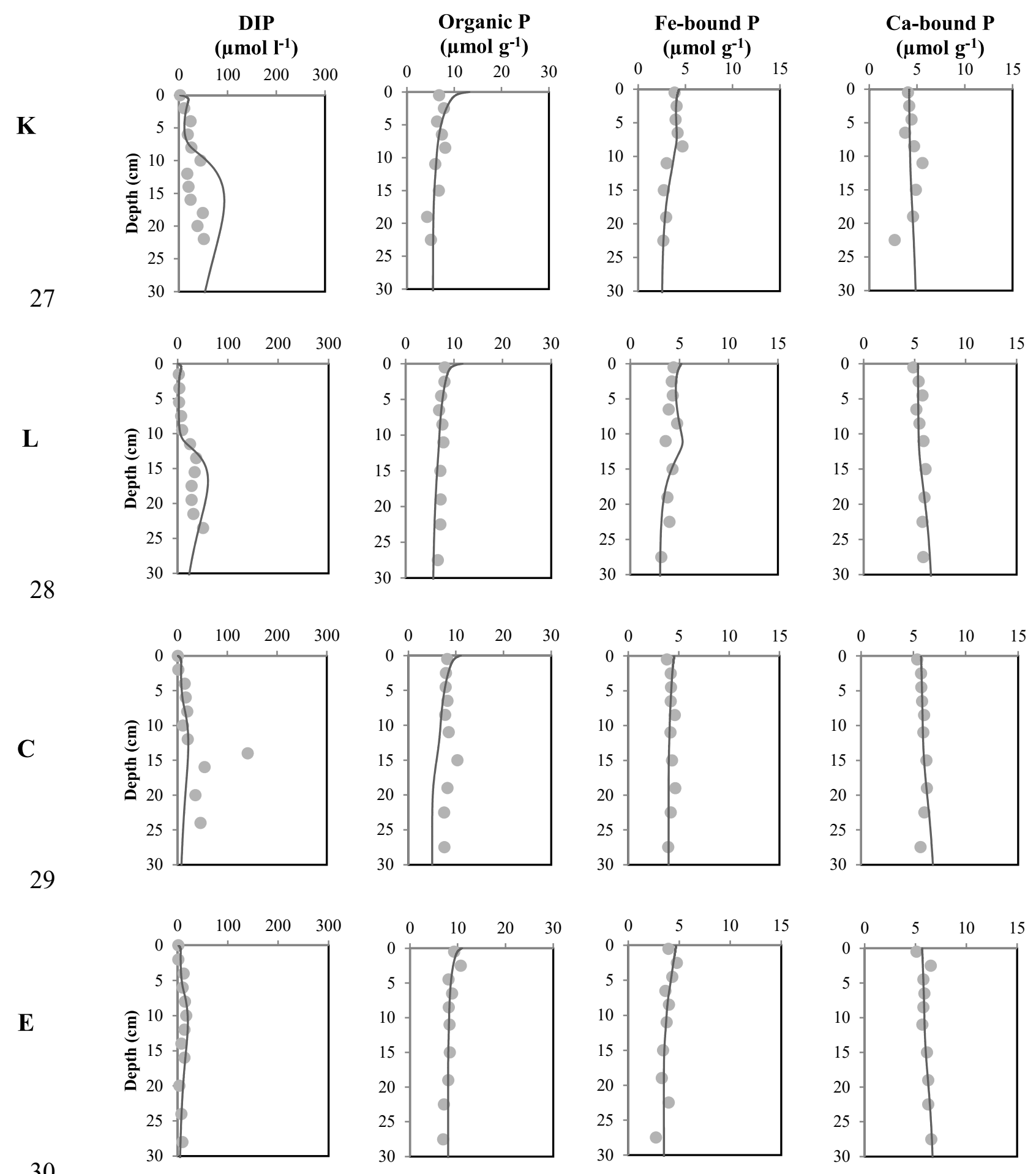

31 Fig. 4 Simulated (grey lines) and measured (symbols (•)) DIP, organic P, Fe-bound P and 


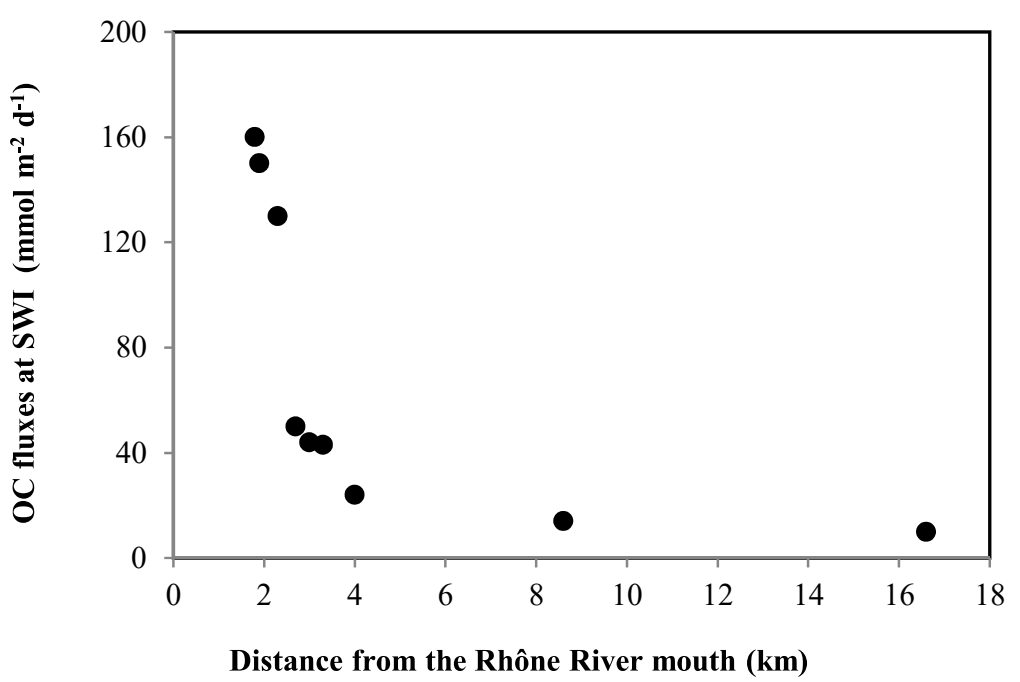

33

Fig. 5 Metabolized OC fluxes at sediment-water interface along the Rhône River

prodelta 
a)

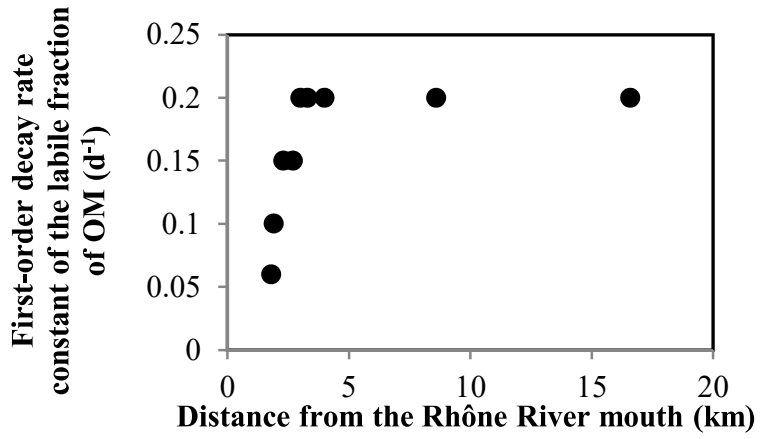

b)

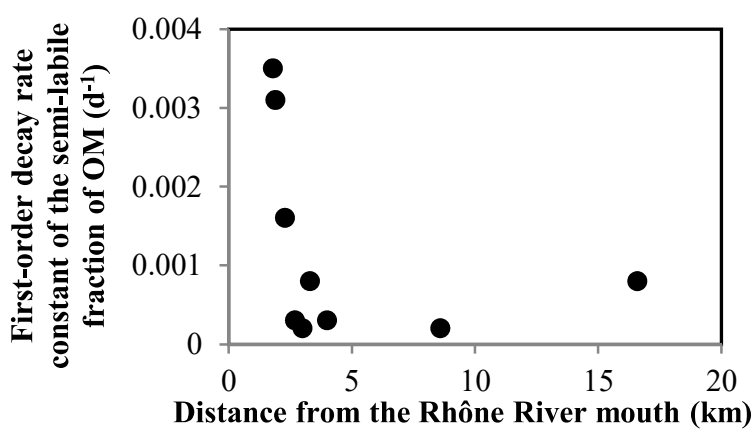




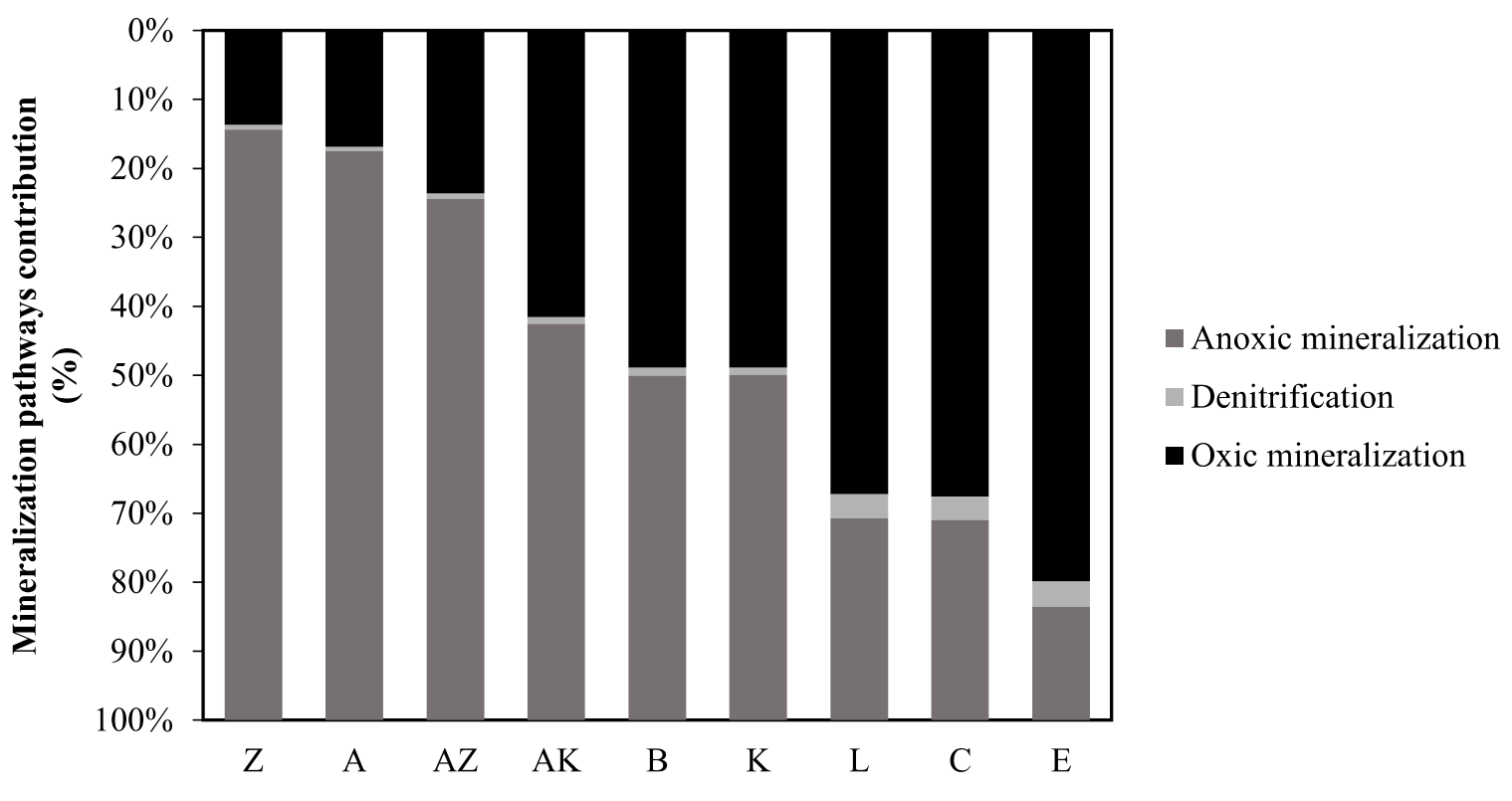

Fig. 7 Mineralization pathways contribution (\%) in the sampled stations 


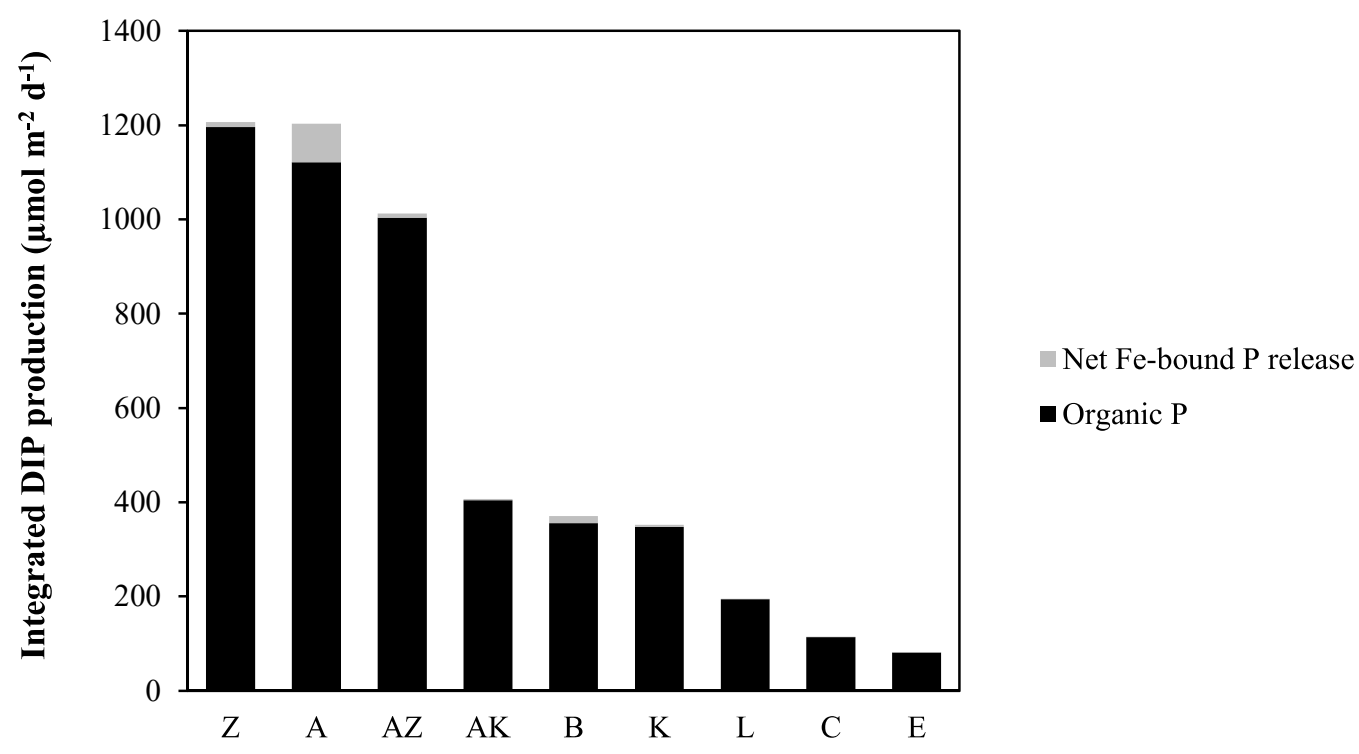

45 Fig. 8 Integrated rates of DIP production $\left(\mu \mathrm{mol} \mathrm{m} \mathrm{m}^{-2} \mathrm{~d}^{-1}\right)$, for organic $\mathbf{P}$ mineralization and net $\mathrm{Fe}-$ bound $\mathrm{P}$ release. 


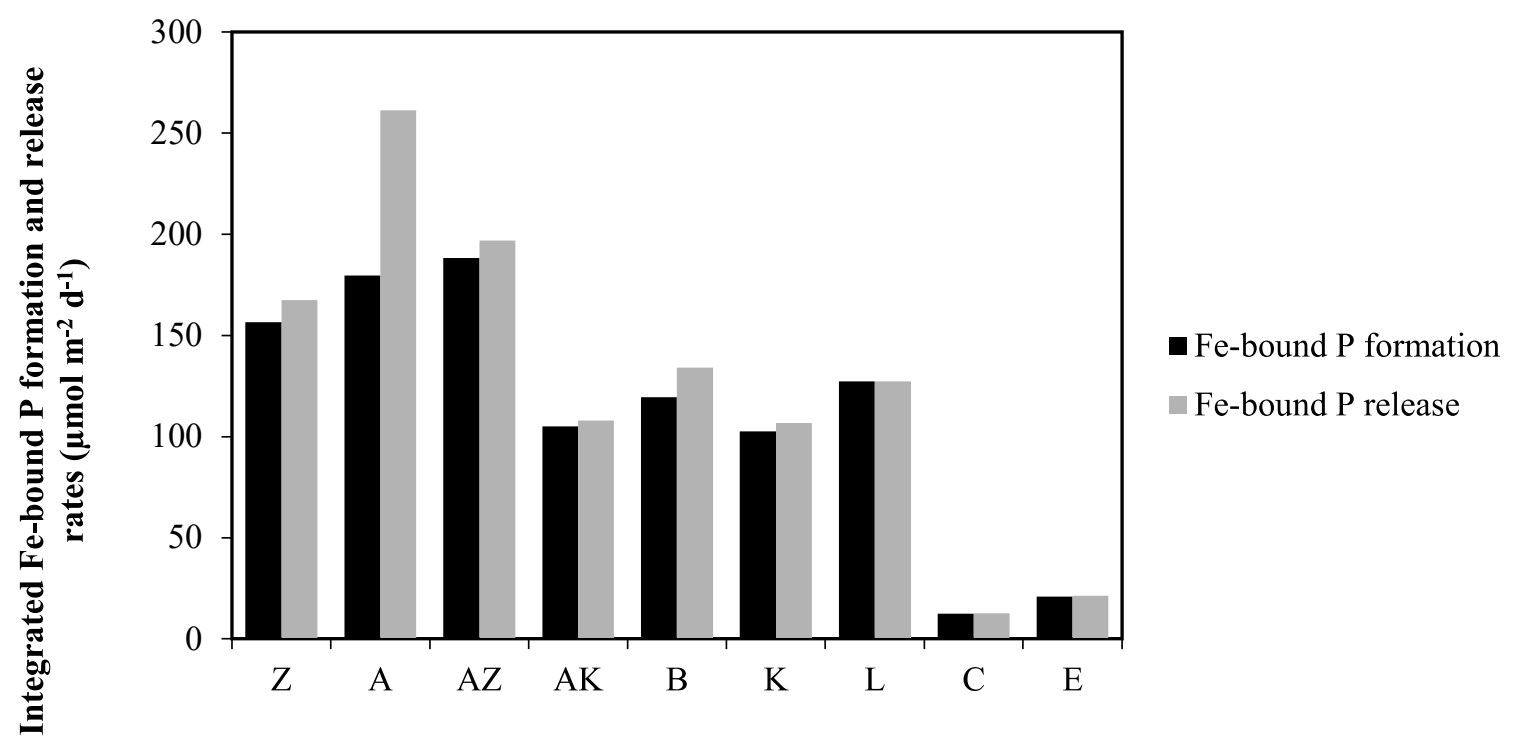




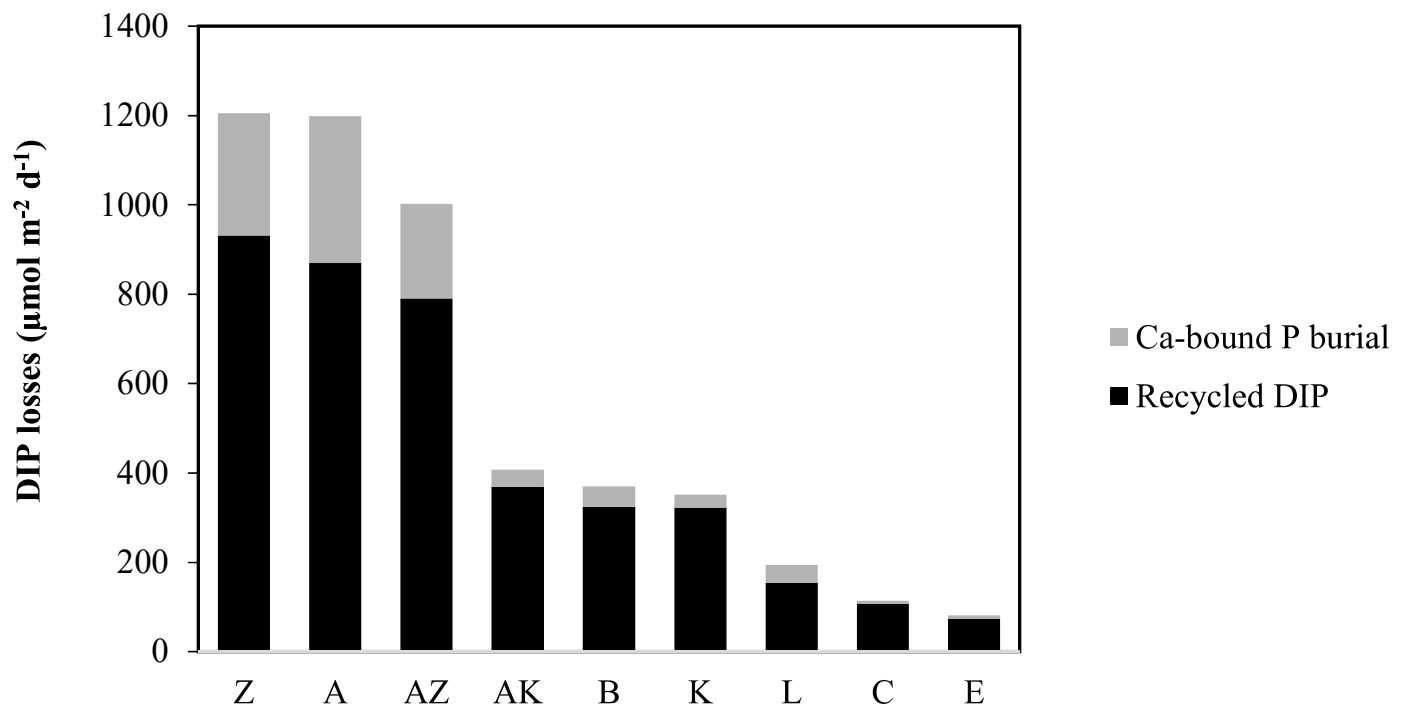




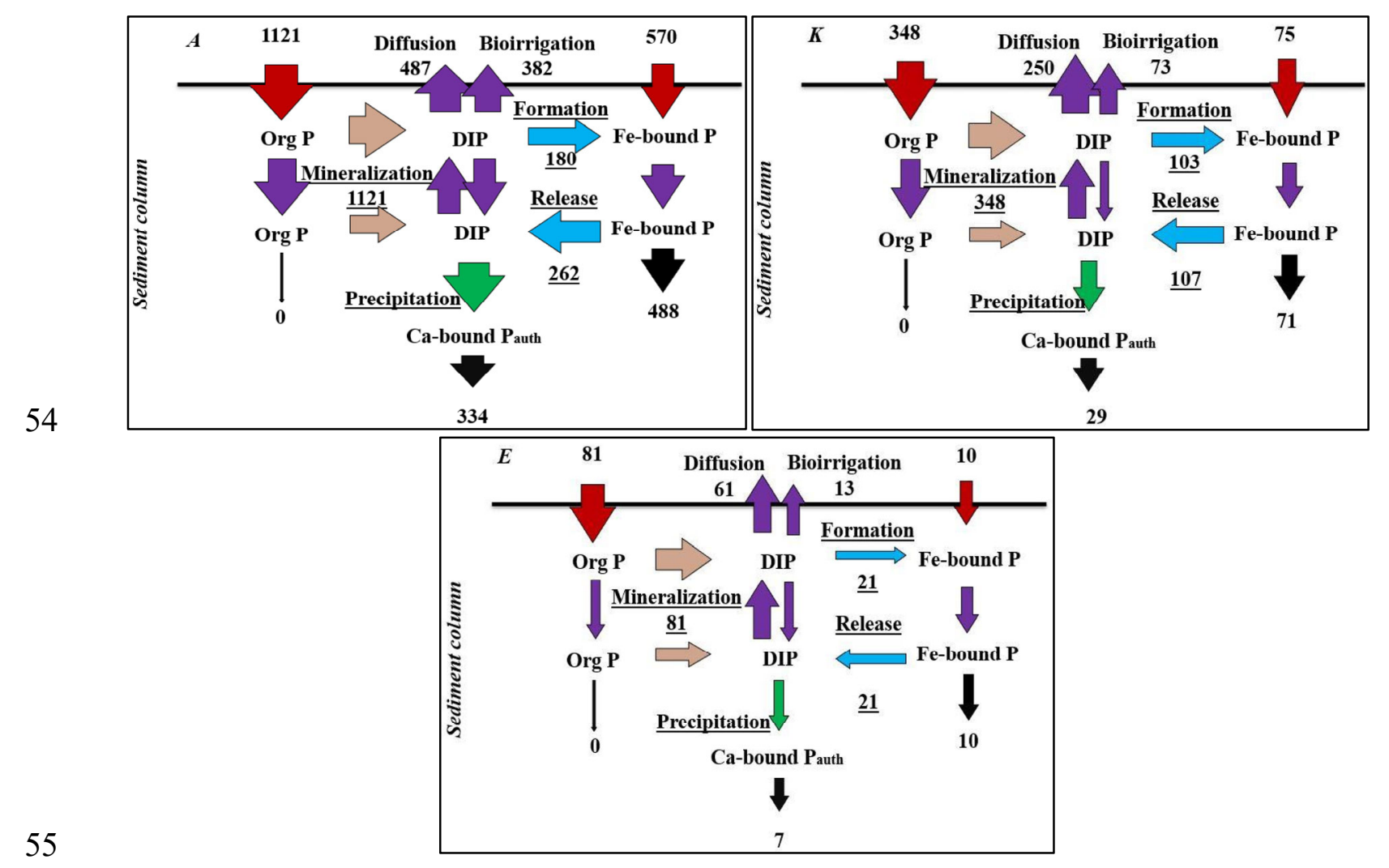

56

57 Fig. 11 Sedimentary $\mathbf{P}$ budgets $\left(\mu \mathrm{mol} \mathrm{m} \mathrm{m}^{-2} \mathrm{~d}^{-1}\right)$ for typical stations of the different zones of 58 the Rhône River prodelta: proximal (station A), prodelta (station K) and distal domains (station E) 


\section{Tables}

2

3

4

5

Table 1 Sampling site locations and environmental parameters (bottom water (1) temperature $\mathrm{T}_{\mathrm{bw}}$ and salinity $\mathrm{S}$ ) for each station during the benthic sampling

\begin{tabular}{ccccccc}
\hline Site & Lat. $\left({ }^{\circ} \mathbf{N}\right)$ & Long. $\left({ }^{\circ} \mathbf{E}\right)$ & Dist. & Depth $(\mathbf{m})$ & $\mathbf{T}_{\text {bw }}\left({ }^{\circ} \mathbf{C}\right)$ & Salinity \\
\hline $\mathbf{Z}$ & $4^{\circ} 19.062^{\prime}$ & $4^{\circ} 52.034^{\prime}$ & 1.8 & 20.2 & 15.7 & 38 \\
\hline $\mathbf{A}$ & $4^{\circ} 18.680^{\prime}$ & $4^{\circ} 51.038^{\prime}$ & 1.9 & 21 & 15.6 & 37.8 \\
\hline $\mathbf{A Z}$ & $43^{\circ} 18.742^{\prime}$ & $4^{\circ} 51.400^{\prime}$ & 2.3 & 20 & 20 & 37.8 \\
\hline $\mathbf{A K}$ & $43^{\circ} 18.426^{\prime}$ & $4^{\circ} 51.300^{\prime}$ & 2.7 & 43.7 & 15.6 & 37.9 \\
\hline $\mathbf{B}$ & $4^{\circ} 18.262^{\prime}$ & $4^{\circ} 49.938^{\prime}$ & 3 & 48.5 & 15.8 & 37.9 \\
\hline $\mathbf{K}$ & $43^{\circ} 18.111^{\prime}$ & $4^{\circ} 51.361^{\prime}$ & 3.3 & 57.3 & 15.7 & 38.5 \\
\hline $\mathbf{L}$ & $43^{\circ} 18.270^{\prime}$ & $4^{\circ} 53.106^{\prime}$ & 4 & 60.8 & 15.1 & 38.1 \\
\hline $\mathbf{C}$ & $43^{\circ} 16.237^{\prime}$ & $4^{\circ} 46.379^{\prime}$ & 8.6 & 72.5 & 14.7 & 38.2 \\
\hline $\mathbf{E}$ & $43^{\circ} 13.333^{\prime}$ & $4^{\circ} 41.897^{\prime}$ & 16.6 & 72 & 14.8 & 38.3 \\
\hline
\end{tabular}

$$
6
$$


Table 2 Mineralization pathways and diagenetic equations in the model

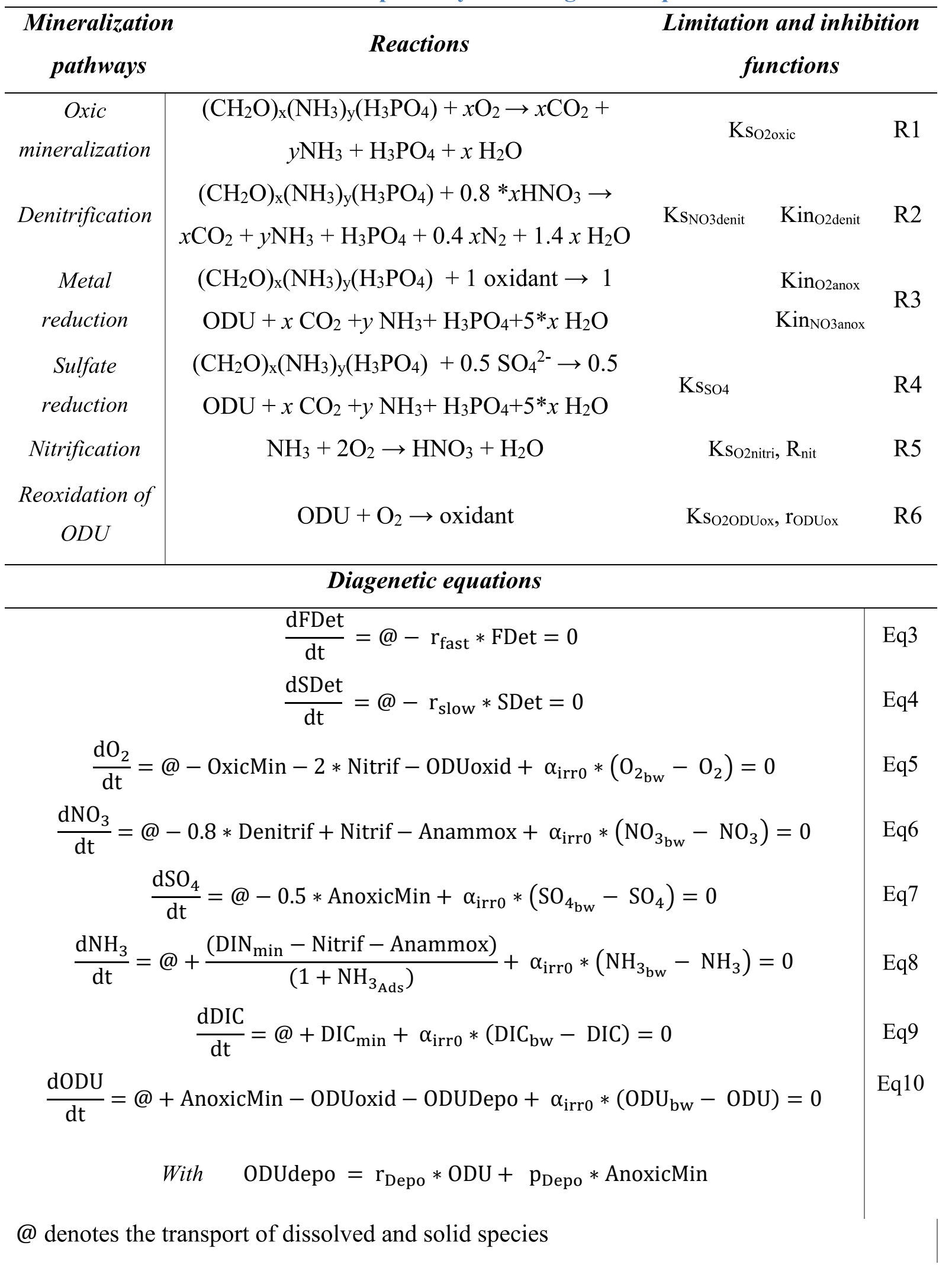




\section{P equations}

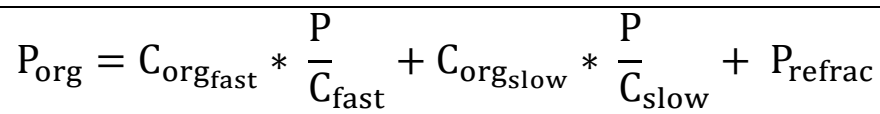

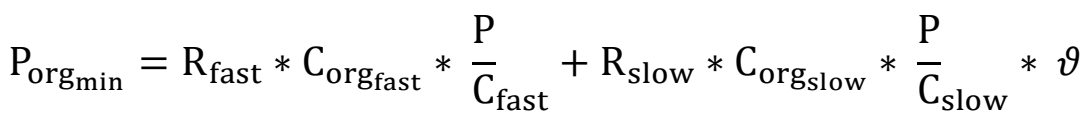

$$
\begin{aligned}
& \text { Fe_bound } \mathrm{P}_{\text {formation }}=\mathrm{R}_{\mathrm{Fe} \_ \text {bound }} \mathrm{P}_{\text {form }} *\left(\mathrm{DIP}-\mathrm{DIP}_{\mathrm{S}}\right) * \mathrm{O}_{2} \text { func } \\
& \mathrm{O}_{2} \text { func }=\frac{\mathrm{O}_{2}}{\left(\mathrm{O}_{2}+0.1\right)} \\
& \text { Ca_bound } \mathrm{P}_{\text {precipitation }}=\mathrm{R}_{\text {Ca_bound }} \mathrm{P}_{\text {precip }} *\left(\mathrm{DIP}-\mathrm{DIP}_{\mathrm{eq}}\right) \\
& \frac{\mathrm{dDIP}}{\mathrm{dt}}=@+\mathrm{P}_{\text {org }_{\min }}-\mathrm{Fe}_{-} \text {boundP } \mathrm{P}_{\text {formation }}+\mathrm{Fe}_{-} \text {boundP } \mathrm{P}_{\text {release }} * \vartheta \\
& - \text { Ca_boundP } \text { precipitation }_{-}+\alpha_{\text {irro }} *\left(\mathrm{DIP}_{\mathrm{bw}}-\mathrm{DIP}\right)=0
\end{aligned}
$$

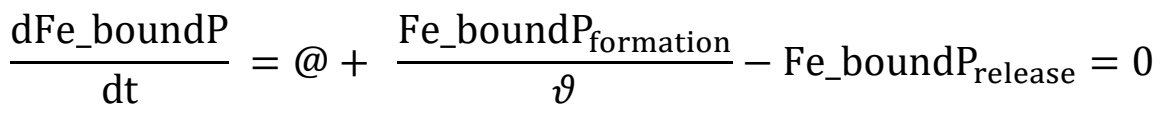

$$
\begin{aligned}
& \frac{\text { dCa_bound P }}{\mathrm{dt}}=@+\frac{\text { Ca_bound Precipitation }}{\vartheta}=0
\end{aligned}
$$

@ denotes the transport of dissolved and solid species 
Table 4 Fixed parameters in the model are the ammonium adsorption coefficient (NH3Ads), maximum oxidation of ODU (roDUox) and nitrification rate constants ( $r_{n i t}$ ), half-saturation constants for $\mathrm{O}_{2}$ limitation for oxic mineralization (kso2oxic) and nitrification ((kSO2nitri), nitrate limitation for nitrate reduction (ksNO3denit), $\mathrm{O}_{2}$ limitation

16 for the oxidation of reduced substances (ksO2ODux), $\mathrm{O}_{2}$ inhibition for nitrate reduction

17 (kino2denit) and anoxic mineralization (kino2anox), nitrate inhibition for anoxic

18 mineralization (kinNO3anox), sulfate limitation for sulfate reduction (ksso4), $\mathrm{C} / \mathbf{N}_{\text {fast, }} \mathrm{C} / \mathrm{N}_{\text {slow, }}$ 19 $\mathrm{C} / \mathrm{P}_{\text {fast }}$ and $\mathrm{C} / \mathrm{P}_{\text {slow }}$

\begin{tabular}{|c|c|c|c|}
\hline Parameter & Unit & Value & Source \\
\hline $\mathrm{NH}_{3 A d s}$ & - & 1.3 & $\mathrm{~L}$ \\
\hline roDUox & $\mathrm{d}^{-1}$ & 20 & $\mathrm{~L}$ \\
\hline Rnit & $\mathrm{d}^{-1}$ & 10 & $\mathrm{C}$ \\
\hline Ksozoxic & $\mu \mathrm{mol} \mathrm{O} \mathrm{I}^{-1}$ & 1 & $\mathrm{~L}$ \\
\hline Kso2nitri & $\mu \mathrm{mol} \mathrm{O} \mathrm{l}^{-1}$ & 10 & $\mathrm{~L}$ \\
\hline KsNO3denit & $\mu \mathrm{mol} \mathrm{NO}{ }^{-} 1^{-1}$ & 10 & $\mathrm{~L}$ \\
\hline KSO2ODUox & $\mu \mathrm{mol} \mathrm{O} 1^{-1}$ & 1 & $\mathrm{~L}$ \\
\hline Kino2denit & $\mu \mathrm{mol} \mathrm{O} \mathrm{I}^{-1}$ & 1 & $\mathrm{~L}$ \\
\hline Kino2anox & $\mu \mathrm{mol} \mathrm{O} \mathrm{O}^{-1}$ & 1 & $\mathrm{~L}$ \\
\hline Kin $_{\text {NO3anox }}$ & $\mu \mathrm{mol} \mathrm{NO}{ }^{-} 1^{-1}$ & 10 & $\mathrm{~L}$ \\
\hline Ksso4 & $\mathrm{mmol} \mathrm{SO}_{4}^{2-} 1^{-1}$ & 800 & $\mathrm{~L}$ \\
\hline$C / N_{\text {fast }}$ & $\mathrm{mol} \mathrm{C} \mathrm{mol} \mathrm{N}{ }^{-1}$ & 7.1 & $\mathrm{~L}$ \\
\hline$C / N_{\text {slow }}$ & $\mathrm{mol} \mathrm{C} \mathrm{mol} \mathrm{N} \mathrm{N}^{-1}$ & 10 & $\mathrm{~L}$ \\
\hline $\boldsymbol{C} / \boldsymbol{P}_{\text {fast }}$ & $\mathrm{mol} \mathrm{C} \mathrm{mol} \mathrm{P}{ }^{-1}$ & 114 & $\mathrm{C}$ \\
\hline $\boldsymbol{C} / \boldsymbol{P}_{\text {slow }}$ & $\mathrm{mol} \mathrm{C} \mathrm{mol} \mathrm{P} \mathrm{P}^{-1}$ & 160 & $\mathrm{C}$ \\
\hline$D I P s$ & $\mu \mathrm{mol}^{-1}$ & 1 & $\mathrm{~L}$ \\
\hline
\end{tabular}


Table 5 Parameters measured in every sampled station: bottom water dissolved species concentrations $C_{b w}$, porosity parameters $\left(\varnothing_{0}, \varnothing_{\infty}\right.$ and coeffø), bottom water temperature, salinity and sedimentation rate ( $(\omega)$

\begin{tabular}{|c|c|c|c|c|c|c|c|c|c|c|}
\hline Parameter & Unit & $Z$ & $A$ & $A Z$ & $A K$ & $B$ & $K$ & $L$ & C & $E$ \\
\hline Temperature & ${ }^{\circ} \mathrm{C}$ & 15.7 & 15.6 & 20 & 15.6 & 15.8 & 15.7 & 15.1 & 14.7 & 14.8 \\
\hline Salinity & $\mathrm{g} \mathrm{kg}^{-1}$ & 38 & 37.8 & 37.8 & 37.9 & 37.9 & 38.2 & 38.1 & 38.2 & 38.3 \\
\hline$O_{2 b w}$ & $\mu \mathrm{mol} \mathrm{l}^{-1}$ & 215 & 197 & 206 & 185 & 206 & 206 & 235 & 189 & 224 \\
\hline $\mathrm{NO}_{3 b w}$ & $\mu \mathrm{mol} \mathrm{1}^{-1}$ & 0.8 & 0 & 0.2 & 0 & 0 & 0 & 0.7 & 3 & 2.7 \\
\hline $\mathrm{NH}_{3 b w}$ & $\mu \mathrm{mol} 1^{-1}$ & 0 & 0 & 0.8 & 0.24 & 0.42 & 0.5 & 1.17 & 1.45 & 0 \\
\hline$D I C_{b w}$ & $\mu \mathrm{mol} \mathrm{1}^{-1}$ & 2372 & 2360 & 2330 & 2350 & 2359 & 2363 & 2384 & 2396 & 2377 \\
\hline$D I P_{b w}$ & $\mu \mathrm{mol} \mathrm{l}^{-1}$ & 0.78 & 4.28 & 2.03 & 1.63 & 1.95 & 2.31 & 0.57 & 0.31 & 1.56 \\
\hline$S \boldsymbol{O}_{4 b w}$ & $\mathrm{mmol} \mathrm{l}^{-1}$ & 29.9 & 30.2 & 30.5 & 30.6 & 30.7 & 30.3 & 30.6 & 30.5 & 30.6 \\
\hline$O D U_{b w}$ & $\mu \mathrm{mol} \mathrm{l}^{-1}$ & 0 & 0 & 0.77 & 0 & 0.31 & 0.18 & 0 & 0 & 0 \\
\hline$\omega$ & $\mathrm{cm} \mathrm{y}^{-1}$ & 10 & 10 & 10 & 1 & 1 & 1 & 1 & 0.1 & 0.1 \\
\hline $\boldsymbol{\emptyset}_{0}$ & - & 0.81 & 0.83 & 0.8 & 0.84 & 0.83 & 0.76 & 0.84 & 0.86 & 0.85 \\
\hline $\boldsymbol{\sigma}_{\infty}$ & - & 0.65 & 0.65 & 0.65 & 0.62 & 0.6 & 0.58 & 0.63 & 0.64 & 0.6 \\
\hline $\operatorname{coeff}_{\theta}$ & $\mathrm{cm}$ & 1 & 2 & 3 & 2 & 2 & 3 & 2 & 3 & 6 \\
\hline
\end{tabular}


Table 6 Parameters estimated by the model: organic carbon flux $\left(\mathrm{OC}_{\text {flux }}\right)$, proportion of the labile organic carbon fraction ( $\left.\mathrm{P}_{\text {fast }}\right)$, labile and semi-labile carbon mineralization rate constants ( $R_{\text {fast }}$ and Rslow, respectively), bioturbation parameters (surface bio bioturbation constant $\mathrm{D}_{\mathrm{b} 0}$, thickness of bioturbated layer $\mathrm{x}_{\mathrm{b}}$ ), irrigation parameters (surface irrigation concentration airr0, irrigation depth xirr), Fe-bound P fluxes to sediment-water interface, rate constants for Fe-bound $\mathbf{P}$ formation $\left(\mathbf{R}_{\mathrm{Fe}-\text { bound Pform) }}\right.$ and release ( $\mathbf{R}_{\mathrm{Fe}-\text { bound }}$ Prel), and the

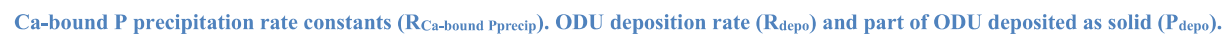

\begin{tabular}{|c|c|c|c|c|c|c|c|c|c|c|}
\hline Parameter & Unit & $Z$ & $\boldsymbol{A}$ & $A Z$ & $A K$ & $B$ & $\boldsymbol{K}$ & $L$ & $C$ & $E$ \\
\hline$O C_{f l u x}$ & $\mathrm{mmol} \mathrm{m} \mathrm{m}^{-2} \mathrm{~d}^{-1}$ & 160 & 150 & 130 & 50 & 44 & 43 & 24 & 14 & 10 \\
\hline $\boldsymbol{R}_{\text {fast }}$ & $\mathrm{d}^{-1}$ & 0.06 & 0.1 & 0.15 & 0.15 & 0.2 & 0.2 & 0.2 & 0.2 & 0.2 \\
\hline $\boldsymbol{R}_{\text {slow }}$ & $\mathrm{d}^{-1}$ & 0.0035 & 0.0031 & 0.0016 & 0.0003 & 0.0002 & 0.0008 & 0.0003 & 0.0002 & 0.0008 \\
\hline$P_{\text {fast }}$ & - & 0.5 & 0.5 & 0.6 & 0.75 & 0.75 & 0.75 & 0.75 & 0.75 & 0.75 \\
\hline $\boldsymbol{R}_{\text {depo }}$ & $\mathrm{d}^{-1}$ & 0.05 & 0.05 & 0.05 & 0.05 & 0.1 & 0.03 & 0.08 & 0.05 & 0.07 \\
\hline$p_{\text {depo }}$ & - & 0.99 & 0.97 & 0.97 & 0.9 & 0.9 & 0.9 & 0.92 & 0.92 & 0.98 \\
\hline$D_{b \theta}$ & $\mathrm{cm}^{2} \mathrm{~d}^{-1}$ & 0.01 & 0.01 & 0.01 & 0.01 & 0.01 & 0.01 & 0.01 & 0.015 & 0.015 \\
\hline$x_{b}$ & $\mathrm{~cm}$ & 5 & 5 & 5 & 10 & 10 & 10 & 10 & 10 & 10 \\
\hline$\alpha_{i r r 0}$ & $\mathrm{~d}^{-1}$ & 0.09 & 0.23 & 0.1 & 0.1 & 0.05 & 0.1 & 0.1 & 0.05 & 0.05 \\
\hline$x_{i r r}$ & $\mathrm{~cm}$ & 8 & 7 & 14.5 & 9 & 13 & 8 & 11 & 7 & 6 \\
\hline$C_{r e f}$ & $\%$ & 1 & 1.35 & 1 & 1 & 1.25 & 1.4 & 1.2 & 0.9 & 1 \\
\hline$P_{r e f}$ & $\mu \mathrm{mol} \mathrm{g}{ }^{-1}$ & 4 & 8 & 5 & 4 & 2.5 & 5.5 & 5.5 & 5 & 8 \\
\hline $\boldsymbol{R}_{\text {Fe-bound Pform }}$ & $\mathrm{d}^{-1}$ & 0.8 & 0.8 & 0.8 & 0.8 & 0.8 & 0.8 & 0.8 & 0.1 & 0.1 \\
\hline $\boldsymbol{R}_{\text {Fe-bound Prel }}$ & $\mathrm{d}^{-1}$ & 0.0008 & 0.0008 & 0.0008 & 0.0008 & 0.0005 & 0.0005 & 0.0008 & 0.0008 & 0.0008 \\
\hline $\boldsymbol{R}_{\text {Ca-bound Pprecip }}$ & $\mathrm{d}^{-1}$ & 0.006 & 0.0055 & 0.003 & 0.003 & 0.003 & 0.002 & 0.006 & 0.002 & 0.0035 \\
\hline Fe-bound P Flux & $\mu \mathrm{mol} \mathrm{m}{ }^{-2} \mathrm{~d}^{-1}$ & 73 & 57 & 73 & 8 & 8.2 & 7.5 & 7.5 & 1 & 1 \\
\hline Fe-bound $P_{\text {Asymp }}$ & $\mu \mathrm{mol} \mathrm{g}{ }^{-1}$ & 3 & 2 & 3 & 3 & 2.5 & 2.5 & 3 & 4 & 3.5 \\
\hline Ca-bound Pher & $\mu \mathrm{mol} \mathrm{g}^{-1}$ & 4 & 4 & 3.6 & 4.7 & 4.1 & 4.15 & 5.3 & 4.7 & 4.2 \\
\hline
\end{tabular}


31 Table 7 Phosphorus budget for the Rhone River and prodelta. Surface area are from 32 Lansard et al. (2009) and Cathalot et al. (2008). River DIP discharge are from Ludwig et 33 al., (2009) and Malago et al. (2019). The benthic DIP flux and Ca-bound P burial are 34 estimated from the model calculations of this study averaged for each homogeneous zone.

36

\begin{tabular}{|c|c|c|c|c|c|c|}
\hline Zones & $\begin{array}{l}\text { Surface } \\
\text { area } \\
\left(\mathrm{km}^{2}\right)\end{array}$ & $\begin{array}{l}\text { Benthic DIP flux } \\
\left(\mu \mathrm{mol} \mathrm{m}{ }^{-2} \mathrm{~d}^{-1}\right)\end{array}$ & $\begin{array}{l}\text { Ca-bound P } \\
\text { burial ( } \mu \mathrm{mol} \\
\left.\qquad \mathrm{m}^{-2} \mathrm{~d}^{-1}\right)\end{array}$ & $\begin{array}{l}\text { DIP Recycl. } \\
\left(\mathrm{kmol} \mathrm{y}^{-1}\right)\end{array}$ & $\begin{array}{c}\text { Ca-bound P } \\
\text { Burial } \\
\left(\mathrm{kmol} \mathrm{y}^{-1}\right)\end{array}$ & $\begin{array}{l}\text { River DIP } \\
\text { discharge } \\
\left(\mathrm{kmol} \mathrm{y}^{-1}\right)\end{array}$ \\
\hline Proximal (A-AZ-Z) & 15 & 864 & 272 & 4728 & 1488 & \\
\hline Prodelta (B-L-K-AK) & 50 & 292 & 39 & 5336 & 703 & \\
\hline Contin. Shelf (C-E) & 200 & 90 & 7 & 6606 & 508 & \\
\hline Total & & & & 16671 & 2699 & $88968^{a} / 47258^{b}$ \\
\hline \multicolumn{4}{|c|}{ Fraction of River DIP discharge (\%) } & $19^{\mathbf{a}}-35^{\mathbf{b}} \%$ & $3^{a}-6^{b} \%$ & \\
\hline
\end{tabular}

$37 \quad{ }^{a}$ DIP River discharge from Ludwig et al., 2009; fractions calculated with respect to the 38 discharge by Ludwig et al., 2009.

40 discharge by Malago et al., 2019. 